Article

\title{
A Structurally Diverse Heterocyclic Library by Decoration of Oxcarbazepine Scaffold
}

\author{
Luca Vaghi $^{1 \text {,*, Emanuela Calcio Gaudino }}{ }^{2}$, Giancarlo Cravotto ${ }^{2}$, Giovanni Palmisano ${ }^{1}$ \\ and Andrea Penoni ${ }^{1}$
}

1 Dipartimento di Scienza e Alta Tecnologia, Università degli Studi dell' Insubria, via Valleggio 11, Como 22038, Italy; E-Mails: giovanni.palmisano@uninsubria.it (G.P.); andrea.penoni@uninsubria.it (A.P.)

2 Dipartimento di Scienza e Tecnologia del Farmaco, Università degli Studi di Torino, via Giuria 9, Torino 10125, Italy; E-Mails: emanuela.calcio@unito.it (E.C.G.); giancarlo.cravotto@unito.it (G.C.)

* Author to whom correspondence should be addressed; E-Mail: luca.vaghi@uninsubria.it; Tel.: +39-031-238-6440; Fax: +39-031-238-6449.

Received: 8 October 2013; in revised form: 1 November 2013 Accepted: 4 November 2013 / Published: 6 November 2013

\begin{abstract}
A library of new heterocyclic systems was synthesized starting from oxcarbazepine (OXC, Trileptal ${ }^{\circledR}$, 10-oxo-10,11-dihydro-5H-dibenzo[b,f]azepine-5-carboxamide). The key for these transformations is the $\alpha$-enolizable ketone present on the $[d]$-side of our starting material $\mathrm{OXC}$, thus, an in depth investigation of the literature to find heteroannulation reactions for substrates carrying an $\alpha$-enolizable ketone gave us a boost to discover an excellent derivatization strategy and [3+2], [4+2] and [4+1] approaches were successfully developed. Almost always a pre-functionalization was needed, but also the direct one-pot heterocycle construction was also explored.
\end{abstract}

Keywords: oxcarbazepine; heteroannulation; library of compound; fused heterocycles; cyclization; cyclocondensation

\section{Introduction}

Oxcarbazepine (OXC, Trileptal ${ }^{\circledR}$, 10-oxo-10,11-dihydro-5H-dibenzo[b,f]azepine-5-carboxamide, 1, Figure 1), known since 1965 [1] and patented by Ciba-Geigy [2] represents the first narrow-spectrum 
antiepileptic drug (AED) in several years to be FDA-approved in 2000 as a monotherapy for the treatment of partial seizures in adults $[3,4]$.

Although the precise mechanism by which OXC exerts its antiseizure effect is unknown, it is well documented that $\mathrm{OXC}$ is completely adsorbed and extensively metabolized (approximately 70\%) by reductase enzymes to its pharmacologically active 10-monohydroxy derivative form eslicarbazepine ((S)-licarbazepine, MHD, Figure 1) [5].

Figure 1. Structures of oxcarbazepine and eslicarbazepine.

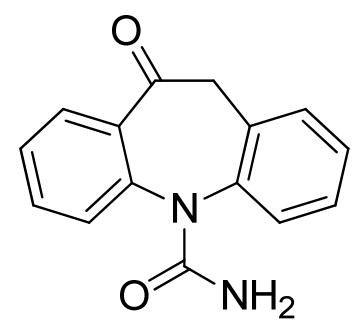

Oxcarbazepine (1)<smiles>NC(=O)N1c2ccccc2CC(O)c2ccccc21</smiles>

Eslicarbazepine

The structure-activity relationships to date have shown that the potency and selectivity of $\mathbf{1}$ are linked to the $\mathrm{N}$-carboxamido group embodied in the twisted boat conformation of the dibenzoazepine core [6]. Accordingly, subsequent synthetic efforts focused on chemical manipulation of the 10-position, mimicking the active MDH with the aim of improving the pharmacological profile [7,8]. At present, an in-depth manipulation of $\mathbf{1}$ in order to find activities other than the anticonvulsant one has not been previously undertaken. Due to our interest in heterocyclic chemistry [9-14] and to the availability in large quantities of $\mathbf{1}$, we envisioned that $\mathbf{1}$ would be a versatile key intermediate for further decoration of the azepine subunit, to obtain a new library of compounds of high potential value in the drug research field. We report herein experimental procedures for the synthesis of compounds based on the template 1 (a large part of them with intact $N$-carboxamido functions). Most reactions were run only once and the reported yields are therefore unoptimized. A diverse set of 5- and 6-membered heterocyclic rings (e.g., oxazole, pyrrole, indole, thiazole, pyrazine, quinoxaline etc) were appended, thereby paving the way to $[d]$-fused heterocycles which have been largely neglected or are totally absent in the literature. This library of compounds will be subjected to high throughput screening for deciphering their biological activity and these results will be reported in due course.

\section{Results and Discussion}

The de novo synthesis of heterocyclic ring systems represents one of the most important topics and this goal was frequently achieved by cyclization strategies. Capitalizing on the presence of a carbonyl function on the $[d]$-side of OXC, the molecules described in this work could be structurally categorized in three classes depending on the type of pre-functionalization of $\mathbf{1}$ required prior to the heterocyclization step: pre-functionalization of position 10 (class a); pre-functionalization of position 11 (class b); no pre-functionalization required (class $c$ ) (Scheme 1). 
Scheme 1. Synthetic strategy en route to new fused heterocycles from oxcarbazepine (1).

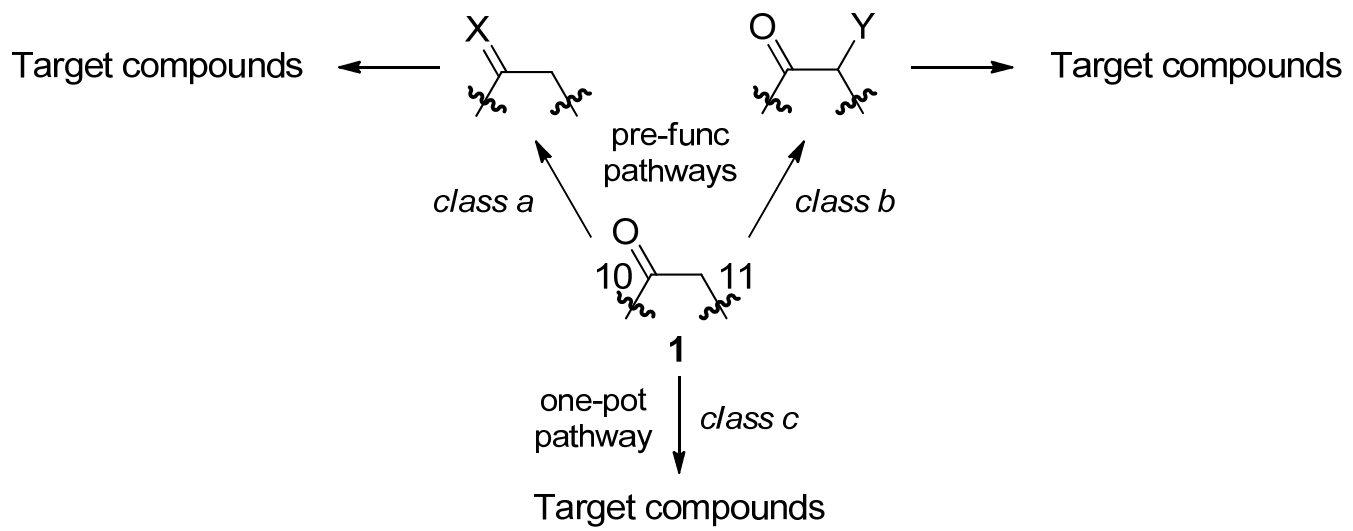

\subsection{Class a}

The venerable (first reported over 120 years ago) Fischer reaction still stands out as one of the most efficient approach to indoles [15,16]. A number of literature methods for indolization of enolizable carbonyls with aryl hydrazines were examined in an effort to convert 1 to 3 (Scheme 2). Attempts to carry out this transformation (with phenylhydrazine and $\mathbf{1}$ as $[\mathrm{C}-\mathrm{C}-\mathrm{N}]$ and $[\mathrm{C}-\mathrm{C}]$ units, respectively, in a [3+2] strategy) in a one-pot procedure under a variety of solvents and acid catalysts resulted in formation of dark mixtures in which only trace amounts of $\mathbf{3}$ could be detected.

Scheme 2. [3+2] Fischer indolization like strategy.

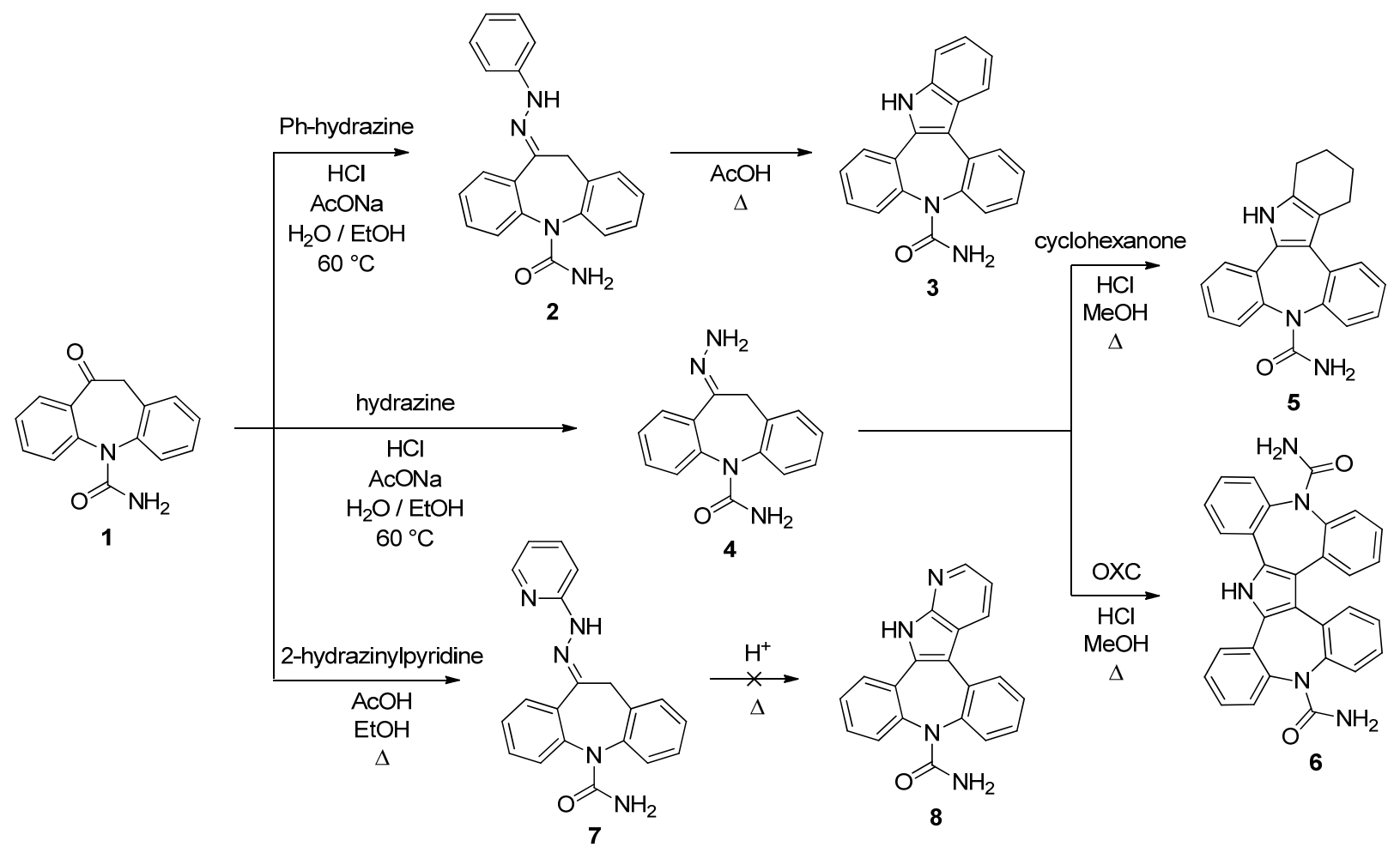

Considerably better results were obtained starting from the known 10-phenylhydrazone 2 [8] which, on exposure to refluxing acetic acid for 1 hour, underwent the desired Fischer indolization and $\mathbf{3}$ was isolated in $79 \%$ yield. However, much to our surprise, exposure of pyrid-2-yl hydrazone 7 to the same 
reaction conditions did not afford the anticipated product $\mathbf{8}$ but rather yielded an intractable mixture of unidentified products. This reaction was attempted several times, producing, in all cases, similar results.

We planned to apply the Fischer strategy using the 10-hydrazone 4 [8] as [C-C-N] unit and cyclohexanone and $\mathrm{OXC}$ (1) itself as $[\mathrm{C}-\mathrm{C}]$ units. In this context we found the hydrazone formation/Fischer indolization $\left(\mathrm{MeOH}, \mathrm{HCl}, 68^{\circ} \mathrm{C}, 30 \mathrm{~min}\right.$.) was the most effective route and therefore 5 and 6 were prepared without significant complications in $69 \%$ and $58 \%$ yield, respectively. Compound 6 is formally the product of a Piloty-Robinson reaction on the transient azine [17,18].

The use of oxime 9 [8] as [C-C-N] unit in a [3+2] approach facilitated considerably the preparation of oxazole- and pyrrole-fused analogues (Scheme 3). In the event, cyclocondensation of 9 with benzoyl chloride in the presence of pyridine $\left(\mathrm{PhCl}, 132{ }^{\circ} \mathrm{C}, 30 \mathrm{~min}\right.$.) [19] gave oxazole 10 in fair (40\%) yield. Furthermore, $\mathbf{9}$ is ideally suited to serve as a starting material to prepare pyrrolo[2,3- $d]$ azepines $\mathbf{1 1}$ by using the modified methodology of Trofimov [20]. Accordingly, 11a was obtained by reaction of 11 with methyl propiolate catalysed by TEA in MeCN-DMF (4:1) at r.t. for 1 hour. The transient $O$-vinyl oxime derivative underwent a tandem [3,3]-sigmatropic rearrangement- cyclocondensation to 11a (57\% isolated yield). This reaction is usually reported [21] to require more drastic conditions (DMSO, $>90{ }^{\circ} \mathrm{C}$ ) than those reported here. It was found that this approach could be successfully extended to other electron-deficient alkynes (e.g., 1-phenyl-2-propyn-1-one and its 4-nitrophenyl derivative) leading to $\mathbf{1 1 b}$ and 11c in 71 and $78 \%$ yield, respectively. It is worth mentioning that reaction of more electrophilic DMAD with 9 under the same conditions failed to provide the expected pyrrole derivative 11d, a consequence presumably of the overwhelming steric effect of the additional $\mathrm{CO}_{2} \mathrm{Me}$ in the six-membered cyclic transition state.

Scheme 3. $[3+2]$ Approach with oxime 9 as [C-C-N] unit.

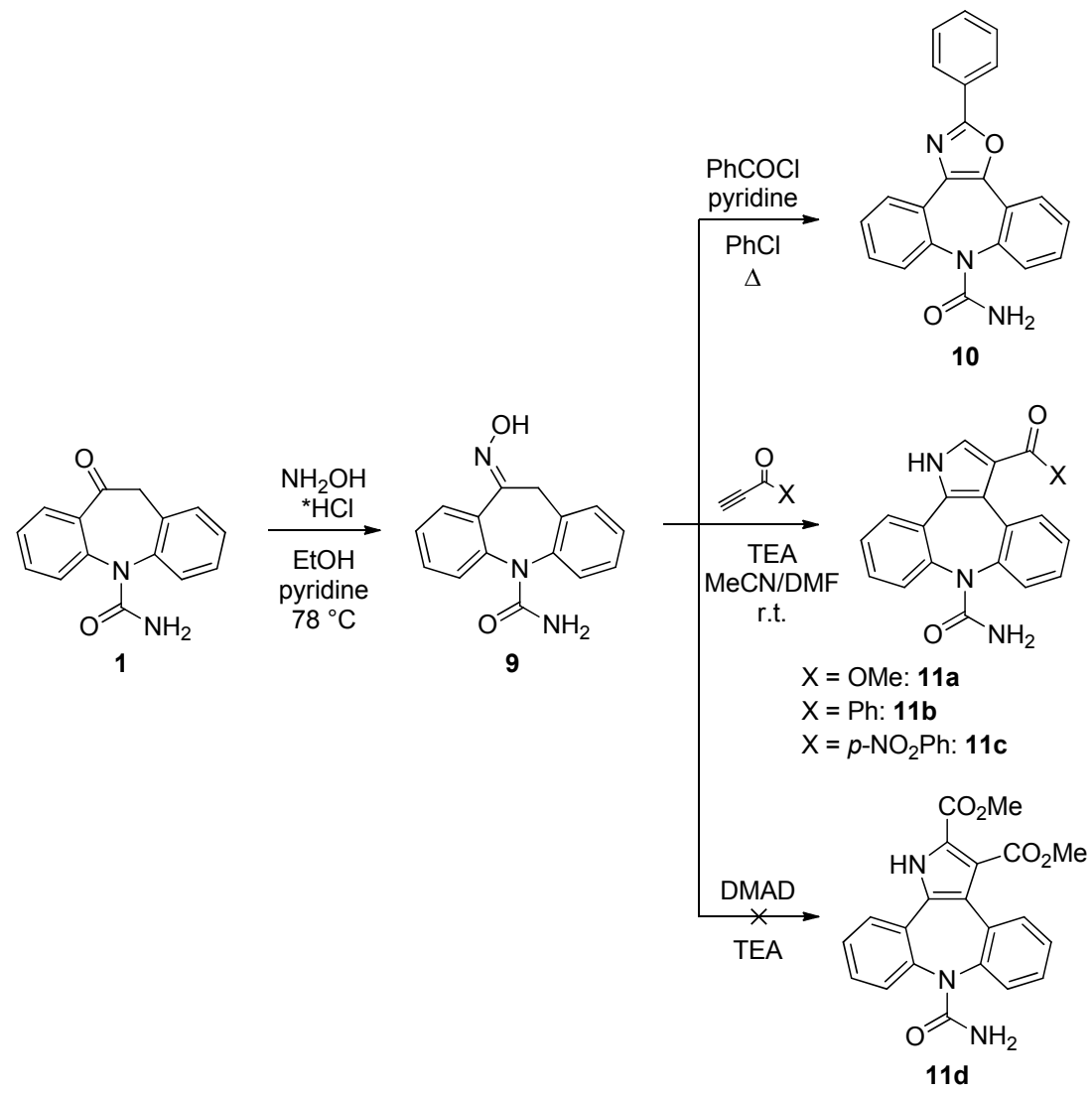


The [4+1] approach is rarely used in the annulation of a carbocyclic scaffold, but it represents the basic mode of accessing heterocycles embodying a N-N-X subunit (Scheme 4). To this end, hetero-cyclization of semicarbazone 12 (as [C-C-N-N] unit) [8] to the corresponding 1,2,3-thiadiazole $9(83 \%)$ was readily accomplished with $\mathrm{SOCl}_{2}$ ([S] unit) [22]. By analogy to the above achieved Hurd-Mori reaction, the treatment of 4 with $\mathrm{SeO}_{2}$ [23] in refluxing $\mathrm{AcOH}$ also proceeded to furnish primarily the selenadiazole $\mathbf{1 0}$ in $48 \%$ yield. A 2007 report by Huazhou et al. [24] describes the high-yielding generation of 2H-1,2,3-diazaphosphole (starting from semicarbazones) through the agency of a $\mathrm{POCl}_{3}-\mathrm{SOCl}_{2}$ mixture and subsequent treatment with EtOH. However, exposure of 4 to these conditions failed to provide the corresponding diazaphosphole $\mathbf{1 5}$ and no further time was invested to understand this failure.

Scheme 4. $[4+1]$ Approach to five-membered diaza heterocycles.

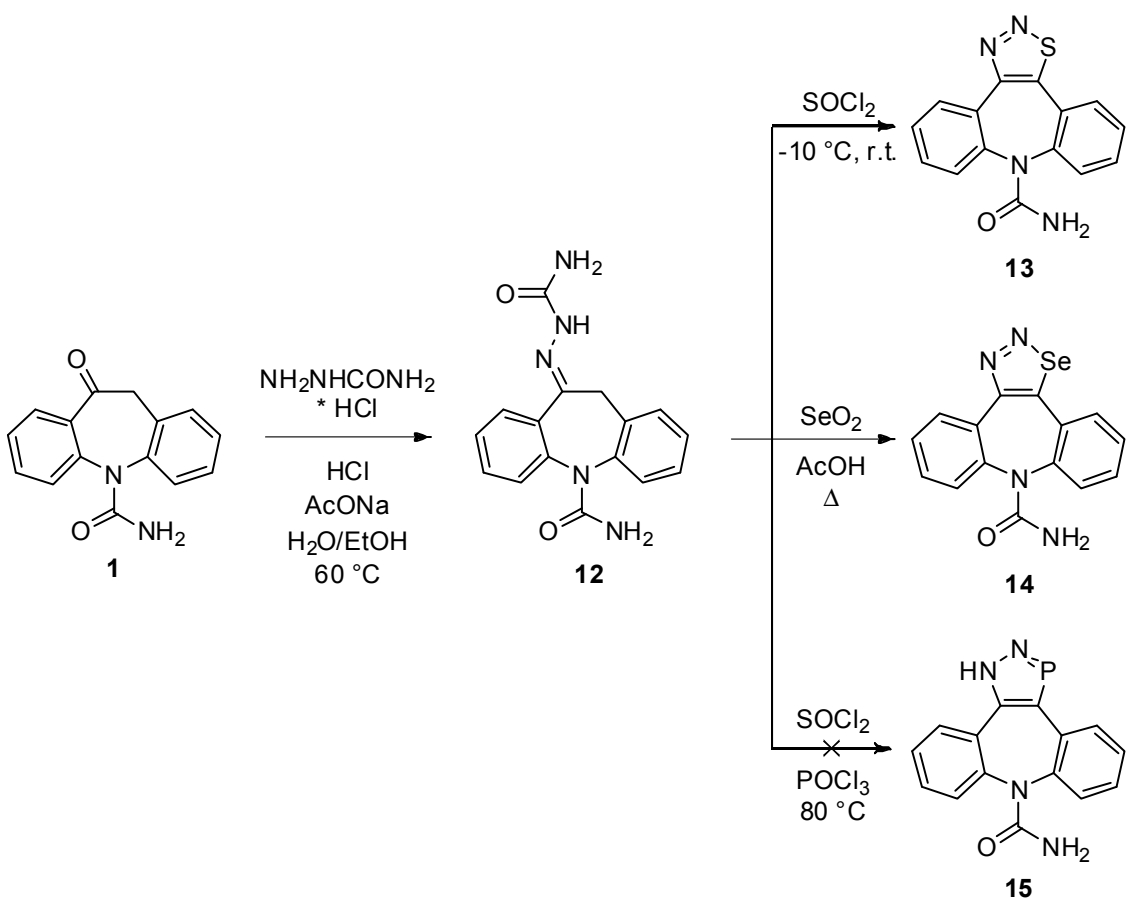

\subsection{Class $b$}

In the second approach (pre-functionalization of the position 11) $\alpha$-bromo ketone $\mathbf{1 5}$ served as pivotal intermediate for further elaboration. It is well known that $\alpha$-halocarbonyls have been successfully exploited in the building of numerous 5- and 6-membered heterocycles [25]. The bromo ketone 16 was prepared by a literature procedure [26] and its reaction with thiourea (Hantzsch reaction) in refluxing EtOH proceeded smoothly and consistently to provide the thiazole derivative $\mathbf{1 7}$ in a pleasing $43 \%$ yield. Spurred by this finding, we set out to explore the reactions of 15 with other 1,3 N,S-bis(nucleophiles) (i.e., benzothioamide b and ethyl 2-amino-2-thioxoacetate c) (Figure 2). 
Figure 2. Reaction of the 11-bromo derivative (16) with 1,3-bis(nucleophiles).<smiles>NC(=O)N1c2ccccc2CC(=O)c2ccccc21</smiles>

1<smiles>NC(=O)N1c2ccccc2C(=O)C(Br)c2ccccc21</smiles>

16<smiles>[X]c1nc2c([nH]1)-c1ccccc1N(C(N)=O)c1ccccc1-2</smiles>

17-24<smiles>CCOC(=O)C(N)=S</smiles>

a

b

c

d<smiles>Nc1nccs1</smiles><smiles>Nc1ccccn1</smiles>

f<smiles>Cc1ccccn1</smiles><smiles>NC(=O)N1c2ccccc2-c2ccccc2-c2nc(N)sc21</smiles>

17<smiles></smiles>

21<smiles>NC(=O)N1c2ccccc2-c2nc(-c3ccccc3)sc2-c2ccccc21</smiles><smiles></smiles>

22<smiles>CCOC(=O)c1nc2c(=O)n(C(N)=O)c3ccccc3c2s1</smiles><smiles>NC(=O)N1c2ccccc2-c2nc(N)oc2-c2ccccc21</smiles><smiles>NC(=O)N1c2ccccc2-c2nc3ncccn3c2-c2ccccc21</smiles>

23<smiles>NC(=O)N1c2ccccc2-c2cc3ccccn3c2-c2ccccc21</smiles>

24

Surprisingly, it was not possible to prepare the corresponding thiazoles $\mathbf{1 8}$ and 19. Reaction conditions (refluxing EtOH) similar to those for $\mathbf{1 7}$ gave no reaction, while higher temperatures (up to $120^{\circ} \mathrm{C}$ in a heavy wall-pressure tube) or prolonged reaction times (up to 6 days) gave inconsistent or messy results. It seemed likely that this failure was due to product/reagent decomposition which ensued at the high temperatures and extended reaction times necessary to heterocyclization, so more robust reagents might be desirable. Accordingly, we chose to examine a structurally diverse set of 1,3 $\mathrm{N}, \mathrm{N}$ - (i.e., 2-amino thiazole e, 2-aminopyridine f and 2-aminopyrimidine $\mathbf{g}$ ), 1,3 N,O- (urea d) and 1,3 $C, N$ - bis(nucleophiles): (2-methylpyridine h) (Figure 2). These substrates were expected to be even less reactive, but these difficulties have been circumvented by switching to butan-1-ol as a solvent with ideal boiling point, solubilization characteristics, and polarity.

We found that heating 16 with 2-aminothiazole e in refluxing $n-\mathrm{BuOH}$ for $6 \mathrm{~h}$ did indeed effect cyclization, providing primarily the thiazole 21 as the only identifiable product in 56\% yield. The optimized reaction conditions were applied to the other representative $N, N-, N, O-$ and $C, N$-bis(nucleophiles). Generally, the yields are satisfactory (32\%-53\% range), the exception being 
2-methylpyridine $\mathbf{h}$, which did not perform well in the Tschitschibabin indolizine synthesis (viz. condensation of $\alpha$-haloketones with 2-alkylpyridines) [27]. The fact that $\mathbf{h}$ did not give any noticeable quantity of the expected $\mathbf{2 5}$ is rather difficult to interpret, and we cannot explain this discrepancy at the moment. Interestingly, routes a and b provided access to an array of diversely substituted derivatives with the $\mathrm{N}$-carboxamido group still attached to azepine core.

Another approach to compounds belonging to class $b$ entailed the installation of an $\alpha$-dicarbonyl function at the $[d]$-edge of the azepine subunit in $\mathbf{1}$ (to 25) followed by the heterocyclization step (Scheme 5). The two-fold benzylic oxidation of carbamazepine CBZ in the presence of a metal salt and $N$-hydroxyphthalimide has been shown by Alsters et al [28] to give the required $\mathbf{2 5}$ (in only $8 \%$ at best!) and, as far as we are aware, this constitutes the only synthesis of this compound. Owing to the availability in large quantities of $\mathbf{1}$, efforts were taken to oxidize it using the Alsters conditions. However, it appeared that this methodology is of limited applicability even to our case. Different methods for oxidation of enolizable carbonyl to $\alpha$-diketones were tested, but they uniformly failed under a range of conditions: the starting material either proved inert or underwent a messy reaction. On exposure to freshly sublimed $\mathrm{SeO}_{2}$ in refluxing dioxane $(7 \mathrm{~h})$ the desired 25 was not observed. Instead, $\alpha$-diketone $\mathbf{2 6}$ was produced as the single reaction product, which crystallized from the crude reaction mixture in $90 \%$ yield. OXC reacted also with benzeneseleninic anhydride in chlorobenzene at $120{ }^{\circ} \mathrm{C}$ for $6 \mathrm{~h}$ to provide the same diketone (87\%). Unfortunately, despite considerable efforts, the oxidation of 1 without compromising the pendant $N$-carboxamido group proved to be fruitless and it was therefore decided to pursue this approach using $\mathbf{2 6}$ as a starting material. Actually, reaction of derivatives devoid of $\mathrm{N}$-carboxamido function with chlorosulphonyl isocyanate (CSI) would help address this problem [29].

Scheme 5. Products of the cyclocondensations on diketo compound 26.
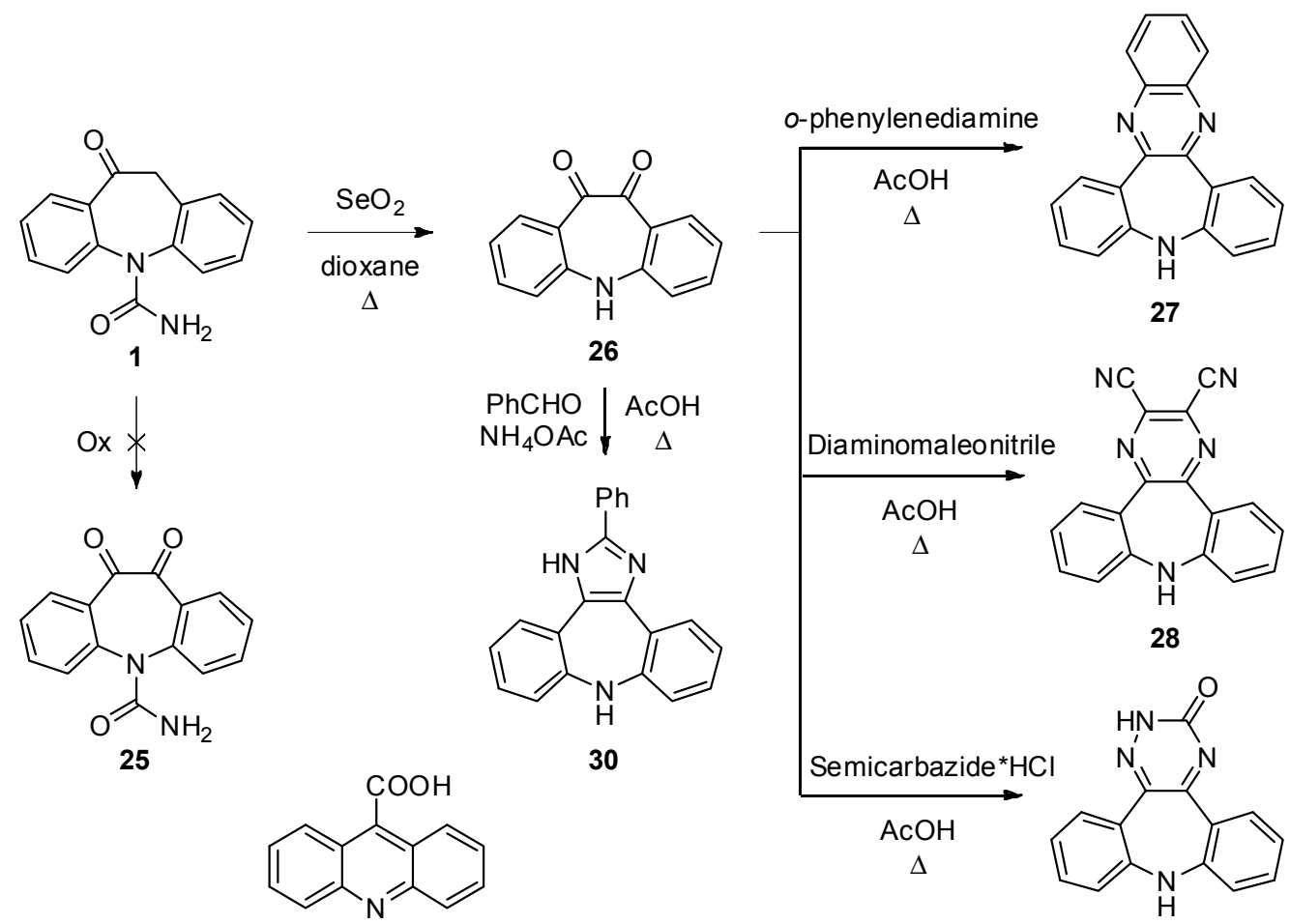

29 
1,2-Dicarbonyl compounds are versatile intermediates for further elaboration leading, i.e., to five- to seven-membered ring systems and $\mathbf{2 6}$ proved to be no exception. Specifically, treatment of a solution of $\mathbf{2 6}$ in $\mathrm{AcOH}$ with $o$-phenylenediamine $\left(118^{\circ} \mathrm{C}, 1 \mathrm{~h}\right)$ effected conversion to the quinoxaline derivative 27 [30].

Following this procedure, either diaminomaleonitrile or semicarbazide hydrochloride participated as 1,4 N,N-bis(nucleophiles) leading to the isolation of pyrazine 28 and triazinone 29 in 65 and 19\% yield, respectively. Further structural diversity could be achieved via MultiComponent Reactions (MCRs). In this context, the reaction of 1,2-dicarbonyls with an aldehyde and $\mathrm{NH}_{3}$, originally developed by Debus and Radziszewski [31], is a remarkably effective method for the preparation of $1 H$-2,4,5-trisubstituted imidazoles. Thus, the $1 H$ - imidazole 30 could be accessed, albeit in a modest $28 \%$ yield, from reaction of 26 with benzaldehyde and $\mathrm{NH}_{4} \mathrm{OAc}$ (as a source of $\mathrm{NH}_{3}$ ) in $\mathrm{AcOH}$ at $80{ }^{\circ} \mathrm{C}$.

The disappointing yields obtained by reacting $\mathbf{2 6}$ under acidic conditions represent the manifestation of the vexing problem associated with ring contraction-dehydration process leading to $\mathbf{3 1}$ as an end-point product.

\subsection{Class c}

In principle, OXC per se could also be the source of additional analogues (Scheme 6) without the need of pre-functionalization (class c). Thus, access to the pentacyclic pyrazolo[1,5- $a$ ]pyridine core in $32(22 \%)$ was easily gained via thermal [3+2] assembly by base-promoted condensation $\left(\mathrm{H}_{2} \mathrm{O} / \mathrm{i}-\mathrm{PrOH}\right.$ $1: 1, \mathrm{~K}_{2} \mathrm{CO}_{3}, 100{ }^{\circ} \mathrm{C}, 2 \mathrm{~h}$ ) of 1-aminopyridinium iodide (as [N-N-C] unit) and $\mathbf{1}$.

Scheme 6. Attempts to direct heteroannulation.
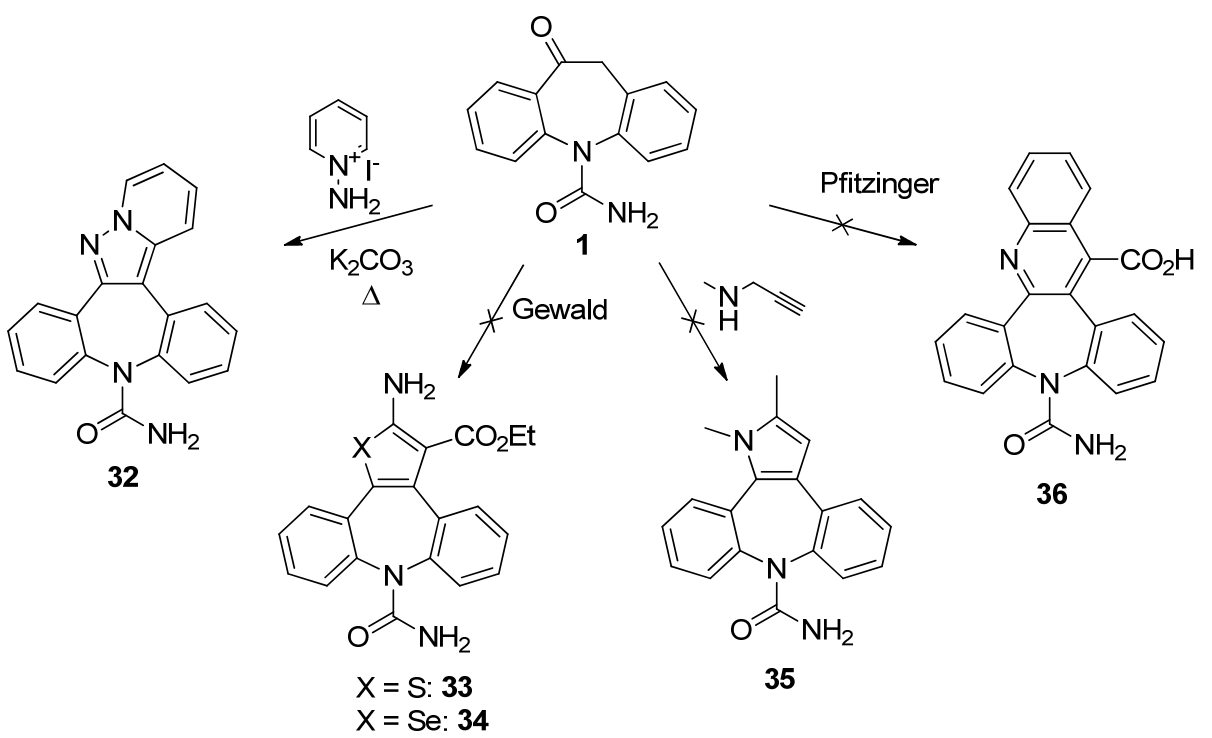

Nevertheless, the participation of $\mathbf{1}$ in other cyclocondensation reactions proved to be a tricky undertaking. The application of Gewald conditions [32] to the reaction of 1 with ethyl cyanoacetate and sulphur in the presence of diethylamine $\left(\mathrm{MeOH}, 65{ }^{\circ} \mathrm{C}, 20 \mathrm{~h}\right)$ provided only extensive decomposition products and no isolable quantities of the expected 2-aminotiophene derivative 33. Furthermore, attempts at replacing sulphur by selenium under the same conditions to achieve a seleno-Gewald multicomponent reaction [33] also gave a complex mixture of products, none of which was the desired 2-aminoselenophene 34. 
In a similar vein, when 1 was subjected to the conditions under which other cyclic ketones were successfully cyclized ( $N$-methyl- $N$-propargylamine, PhMe, $110^{\circ} \mathrm{C}$, sealed tube) to annulated $[b]$ pyrroles through the intermediacy of a $N$-vinyl- $N$-propargylamine [34], no traces of 35 were detected in the reaction mixture over a 8-day time period. Finally, the reluctance of $\mathbf{1}$ to participate in these reactions was also witnessed by the failure met in the Pfitzinger protocol (isatin, $\mathrm{KOH}, \mathrm{H}_{2} \mathrm{O}, 100{ }^{\circ} \mathrm{C}$ ) [35], so this strategy was not pursued further.

\section{Experimental}

All reactions were performed using standard glassware and IKA num heating plates. Reactions utilizing air-sensitive reagents were performed in dried glassware under a nitrogen atmosphere. Solvents were used as received without further purifications. All reagents, if not otherwise specified, were used as received and, if necessary, stored under inert gas. Oxcarbazepine was supplied by Trifarma SpA, Ceriano Laghetto, Italy. For thin-layer chromatography (TLC) analysis Macherey-Nagel Polygram $^{\circledR}$ sil G/UV 254 pre-coated plates were used. Column chromatography was performed on silica gel 60A (70-200 $\mu \mathrm{m})$ (Carlo Erba Reagents, Arese, Italy). Melting point (mp) determinations were performed by using a Gallenkamp melting point apparatus (Weiss-Gallenkamp, Loughborough, UK). ${ }^{1} \mathrm{H}-\mathrm{NMR}(400 \mathrm{MHz})$ and ${ }^{13} \mathrm{C}-\mathrm{NMR}(100 \mathrm{MHz})$ were measured on a AV400 spectrometer (Bruker Corporation, Billerica, MA, USA). Chemical shifts $(\delta)$ are expressed in parts per million (ppm) and coupling constants are given in hertz $(\mathrm{Hz})$. Splitting patterns are indicated as follows: $\mathrm{s}=$ singlet, $\mathrm{d}=$ doublet, $\mathrm{t}=$ triplet, $\mathrm{q}=$ quartet, $\mathrm{m}=$ multiplet, $\mathrm{br}=$ broad, $\mathrm{dd}=$ doublet-doublet, $\mathrm{td}=$ triplet-doublet . Chemical ionization mass spectra (+ve mode) $\left(\mathrm{CI}^{+}-\mathrm{MS}\right)$ were performed on a Finnigan-MAT TSQ70 instrument with isobutane as the reactant gas. Elemental analyses were performed on a Perkin Elmer Series II CHNS/O Analyzer 2400.

10-(Phenylhydrazono)-10,11-dihydro-5H-dibenzo[b,f]azepine-5-carboxamide (2). The compound was prepared following the procedure present in the literature and the spectroscopic data were in accordance with those reported [8]. Yield: $88 \%$.

Dibenzo[2,3:6,7] azepino[4,5-b]indole-9(14H)-carboxamide (3). A well stirred solution of 2 (410 mg, $1.20 \mathrm{mmol})$ in acetic acid $(5 \mathrm{~mL})$ was brought to reflux for $1 \mathrm{~h}$. The reaction progress was monitored by TLC analysis $\left(\mathrm{SiO}_{2}, \mathrm{AcOEt}, R_{f} \mathbf{2}=0.39, R_{f} \mathbf{3}=0.25\right)$. The mixture was then cooled to room temperature and added dropwise to a stirred ice/water solution $(150 \mathrm{~mL})$. The precipitate was filtered, washed with water and dried under vacuum to afford $\mathbf{3}$ as green solid (309 $\mathrm{mg}, 79 \%)$ : ${ }^{1} \mathrm{H}-\mathrm{NMR}$ $\left(\mathrm{DMSO}-d_{6}\right) \delta 11.65(\mathrm{~s}, 1 \mathrm{H}), 7.94(\mathrm{~m}, 2 \mathrm{H}), 7.80(\mathrm{~m}, 1 \mathrm{H}), 7.52(\mathrm{~m}, 3 \mathrm{H}), 7.41(\mathrm{~m}, 3 \mathrm{H}), 7.34(\mathrm{~m}, 1 \mathrm{H})$, $7.21(\mathrm{t}, J=7.3 \mathrm{~Hz}, 1 \mathrm{H}), 7.14(\mathrm{t}, J=7.5 \mathrm{~Hz}, 1 \mathrm{H}), 5.20$ (br. s, $2 \mathrm{H}) .{ }^{13} \mathrm{C}-\mathrm{NMR}$ (DMSO-d $\left.d_{6}\right) \delta 157.2,141.3$, $140.0,137.6,135.0,134.2,130.9,130.1,129.8,129.6,128.7,128.6,128.2,128.1,127.5,126.4,123.4$, 120.8, 120.1, 113.1, 112.6; m.p. 216-219 ${ }^{\circ} \mathrm{C} \mathrm{dec.;} \mathrm{MS}\left(\mathrm{CI}^{+}\right): m / z=326[\mathrm{MH}]^{+}, 283[(\mathrm{M}-\mathrm{HNCO}) \mathrm{H}]^{+}$; Anal. Calcd. for $\mathrm{C}_{21} \mathrm{H}_{15} \mathrm{~N}_{3} \mathrm{O}$ : C, 77.52; H, 4.65; N, 12.91; Found: C, 77.31; H, 4.87; N, 13.01 .

10-Hydrazinylidene-10,11-dihydro-5H-dibenzo[b,f]azepine-5-carboxamide (4). The compound was prepared following the procedure present in the literature and the spectroscopic data were in accordance with those reported [8]. Yield: $45 \%$. 
2,3,4,14-Tetrahydrodibenzo[2,3:6,7]azepino[4,5b]indole-9(1H)-carboxamide (5). Compound 4 (100 mg, $0.38 \mathrm{mmol})$ and cyclohexanone $(45 \mu \mathrm{L}, 0.44 \mathrm{mmol})$ were dissolved in methanol $(15 \mathrm{~mL}) .37 \%$ aq. $\mathrm{HCl}$ $(47 \mu \mathrm{L}, 0.21 \mathrm{mmol})$ was added and the reaction mixture was heated at $68{ }^{\circ} \mathrm{C}$ for $30 \mathrm{~min}$ under stirring. The reaction progress was monitored by TLC analysis $\left(\mathrm{SiO}_{2}, \mathrm{AcOEt}, R_{f} \mathbf{4}=0.04, R_{f} \mathbf{5}=0.22\right)$. After cooling to room temperature and removing part of the solvent under reduced pressure, the solution was dropped into stirred ice/water $(50 \mathrm{~mL})$. The precipitate was filtered, washed with water and dried under vacuum to gave 5 as yellow solid $(85 \mathrm{mg}, 69 \%)$ : ${ }^{1} \mathrm{H}-\mathrm{NMR}$ (DMSO- $\left.d_{6}\right) \delta 11.20(\mathrm{~s}, 1 \mathrm{H}), 7.55-7.28$ (m, 8H), 5.43 (br. S, 2H), $2.90(\mathrm{~m}, 1 \mathrm{H}), 2.72-2.50(\mathrm{~m}, 3 \mathrm{H}), 1.97(\mathrm{~m}, 2 \mathrm{H}), 1.75(\mathrm{~m}, 1 \mathrm{H}), 1.60(\mathrm{~m}, 1 \mathrm{H})$; ${ }^{13} \mathrm{C}-\mathrm{NMR}\left(\mathrm{DMSO}-d_{6}\right) \delta 157.1,139.3,139.2,134.8,131.8,130.3,130.2,130.1,128.1,128.1,128.0$, $127.7,127.3,126.9,126.5,119.1,115.8,24.5,24.1,23.5,23.4$; m.p. $268-269{ }^{\circ} \mathrm{C} ; \mathrm{MS}\left(\mathrm{CI}^{+}\right): \mathrm{m} / z=330$ $[\mathrm{MH}]^{+}, 287[(\mathrm{M}-\mathrm{HNCO}) \mathrm{H}]^{+}$; Anal. Calcd. for $\mathrm{C}_{21} \mathrm{H}_{19} \mathrm{~N}_{3} \mathrm{O}: \mathrm{C}, 76.57 ; \mathrm{H}, 5.81 ; \mathrm{N}, 12.76 ; \mathrm{O}, 4.86$; Found: C, 76.38; H, 5.93; N, 12.49.

5H-Tetrabenzo[b, $\left.b^{\prime}, f, f^{\prime}\right]$ pyrrolo[2,3-d:4,5-d']bisazepine-5,14(19H)-dicarboxamide (6). Compound 1 (111 $\mathrm{mg}, 0.44 \mathrm{mmol})$ and $4(117 \mathrm{mg}, 0.44 \mathrm{mmol})$ were dissolved in hot methanol $(15 \mathrm{~mL})$ and the mixture was stirred at $68{ }^{\circ} \mathrm{C}$ for $10 \mathrm{~min} .37 \%$ aq. $\mathrm{HCl}(47 \mu \mathrm{L}, 0.21 \mathrm{mmol})$ was then added and the solution was left at reflux under stirring for $2 \mathrm{~h}$. The reaction progress was monitored by TLC analysis $\left(\mathrm{SiO}_{2}, \mathrm{AcOEt} / \mathrm{MeOH} 95: 5, R_{f} \mathbf{4}=0.12, R_{f} \mathbf{1}=0.37, R_{f} \mathbf{6}=0.11\right)$. After $30 \mathrm{~min}$ the product started to precipitate as white solid. When the reaction was complete the mixture was cooled to r.t., 6 was recovered in a pure form by filtration and dried in vacuum $\left(124 \mathrm{mg}, 58 \%\right.$ ): ${ }^{1} \mathrm{H}-\mathrm{NMR}$ (DMSO- $\left.d_{6}\right) \delta$ $12.18(\mathrm{~s}, 1 \mathrm{H}), 7.86(\mathrm{~m}, 2 \mathrm{H}), 7.59-7.53(\mathrm{~m}, 4 \mathrm{H}), 7.45(\mathrm{~m}, 4 \mathrm{H}), 7.34(\mathrm{~m}, 4 \mathrm{H}), 7.15(\mathrm{~m}, 2 \mathrm{H}), 5.77$ (br. s, $4 \mathrm{H}) ;{ }^{13} \mathrm{C}-\mathrm{NMR}$ (DMSO-d $d_{6} \delta$ 157.2, 141.1, 140.1, 134.0, 131.6, 130.8, 130.3, 130.0, 129.9, 129.1, 128.2, 128.1, 128.0, 127.9, 119.5; m.p. 336-337 ${ }^{\circ} \mathrm{C}$; $\mathrm{MS}\left(\mathrm{CI}^{+}\right): m / z=484[\mathrm{MH}]^{+}, 441[(\mathrm{M}-\mathrm{HNCO}) \mathrm{H}]^{+}$; Anal. Calcd. for $\mathrm{C}_{30} \mathrm{H}_{21} \mathrm{~N}_{5} \mathrm{O}_{2}$ : C, 74.52; H, 4.38; N, 14.48; Found: C, 74.69; H, 4.27; N, 14.37 .

10-(2-Pyridinylhydrazono)-10,11-dihydro-5H-dibenzo[b,f]azepine-5-carboxamide (7). A mixture of 1 (500 mg, $2.0 \mathrm{mmol})$ and 2-hydrazinopyridine $(654 \mathrm{mg}, 6.0 \mathrm{mmol})$ in ethanol $(20 \mathrm{~mL})$ and three drops of acetic acid was heated at $78{ }^{\circ} \mathrm{C}$ for $1 \mathrm{~h}$ under stirring. The reaction progress was monitored by TLC analysis $\left(\mathrm{SiO}_{2}\right.$, AcOEt, $\left.R_{f} \mathbf{1}=0.26, R_{f} 7=0.07\right)$. After allowing to cool to room temperature, the precipitate was filtered, washed with ethanol and dried in vacuum to give (7) as yellow solid (410 $\mathrm{mg}$, 60\%): ${ }^{1} \mathrm{H}-\mathrm{NMR}\left(\mathrm{DMSO}-d_{6}\right) \delta 10.24$ (br. s, $\left.1 \mathrm{H}\right), 8.20(\mathrm{~d}, J=4.7 \mathrm{~Hz}, 1 \mathrm{H}), 7.95(\mathrm{~m}, 1 \mathrm{H}), 7.69$ (m, 1H), 7.43-7.24 (m, 8H), 6.85 (m, 1H), 5.96 (br. s, 2H), 4.32 (d, $J=17.6 \mathrm{~Hz}, 1 \mathrm{H}), 3.94$ (d, $J=17.6 \mathrm{~Hz}, 1 \mathrm{H})$; ${ }^{13} \mathrm{C}-\mathrm{NMR}\left(\mathrm{DMSO}-d_{6}\right) \delta 158.7,156.9,148.5,144.1,142.5,141.8,138.9,135.5,134.6,130.8,130.0$, 129.7, 129.0, 128.9, 128.8, 128.7, 128.0, 116.6, 108.1, 33.9; m.p. 230-231 ${ }^{\circ} \mathrm{C}$; MS $\left(\mathrm{CI}^{+}\right): m / z=327$ $[\mathrm{MH}]^{+}$; Anal. Calcd. for $\mathrm{C}_{19} \mathrm{H}_{15} \mathrm{~N}_{3} \mathrm{O}_{3}$ : C, 69.96; H, 4.99; N, 20.40; Found: C, 69.75; H, 5.13; N 20.29.

10-(Hydroxyimino)-10,11-dihydro-5H-dibenzo[b,f]azepine-5-carboxamide (9). The compound was prepared following the procedure present in the literature and the spectroscopic data were in accordance with those reported [8]. Yield $=94 \%$.

2-Phenyl-8H-[1,3]oxazolo[4,5-d]dibenzo[b,f] azepine-8-carboxamide (10). 9 (100 mg, $0.37 \mathrm{mmol}$ ), pyridine (30 $\mu \mathrm{L}, 0.37 \mathrm{mmol})$ and benzoyl chloride $(108 \mu \mathrm{L}, 0.93 \mathrm{mmol}$ ) were added to chlorobenzene $(5 \mathrm{~mL})$. The mixture was stirred for $30 \mathrm{~min}$ at r.t., then the temperature was rise to $132{ }^{\circ} \mathrm{C}$ and the 
reaction was stirred for $30 \mathrm{~min}$. The reaction progress was monitored by TLC analysis $\left(\mathrm{SiO}_{2}\right.$, $\mathrm{CH}_{2} \mathrm{Cl}_{2} / \mathrm{EtOH} 95: 5, R_{f} \mathbf{9}=0.13, R_{f} \mathbf{1 0}=0.22$ ). After cooling to r.t. the solvent was removed under reduced pressure, water $(20 \mathrm{~mL})$ was added to the residue and the aqueous phase was extracted with AcOEt $(3 \times 15 \mathrm{~mL})$. The combined organic layers were washed with $\mathrm{H}_{2} \mathrm{O}(2 \times 20 \mathrm{~mL})$, dried $\left(\mathrm{Na}_{2} \mathrm{SO}_{4}\right)$ and the solvent removed under vacuum. Flash column chromatography $\left(\mathrm{SiO}_{2}, \mathrm{CH}_{2} \mathrm{Cl}_{2} / \mathrm{EtOH} 95 / 5\right.$, $\left.R_{f}=0.22\right)$ gave 10 as white solid $(52 \mathrm{mg}, 40 \%)$ : ${ }^{1} \mathrm{H}-\mathrm{NMR}\left(\mathrm{CDCl}_{3}\right) \delta 8.27-8.24(\mathrm{~m}, 2 \mathrm{H}), 8.18-8.16(\mathrm{~m}$, $1 \mathrm{H}), 7.88(\mathrm{dd}, J=7.6,1.5 \mathrm{~Hz}, 1 \mathrm{H}), 7.67-7.50(\mathrm{~m}, 9 \mathrm{H}), 4.61$ (br. s, $2 \mathrm{H}) ;{ }^{13} \mathrm{C}-\mathrm{NMR}\left(\mathrm{CDCl}_{3}\right) \delta 161.7$, $157.7,137.7,137.6,137.1,131.3,130.8,130.5,130.4,130.3,130.3,129.5,129.3,129.1,128.7,128.7$, 127.8, 127.4, 127.2, 125.8; m.p. 230-232 ${ }^{\circ} \mathrm{C}$; $\mathrm{MS}\left(\mathrm{CI}^{+}\right): m / z=354[\mathrm{MH}]^{+}, 382\left[\mathrm{M}^{+} \mathrm{C}_{2} \mathrm{H}_{5}\right]^{+}, 337$ $\left[\left(\mathrm{M}-\mathrm{NH}_{2}\right) \mathrm{H}\right]^{+}, 310$ [(M-HNCO)H] ; Anal. Calcd. for $\mathrm{C}_{22} \mathrm{H}_{15} \mathrm{~N}_{3} \mathrm{O}_{2}: \mathrm{C}, 74.78$; H, 4.28; N, 11.89; Found: C, $74.85 ; \mathrm{H}, 4.22 ; \mathrm{N}, 11.79$.

Methyl-8-carbamoyl-1,8-dihydropyrrolo[2,3-d]dibenzo[b,f]azepine-3-carboxylate (11a). The oxime 9 (200 mg, $0.75 \mathrm{mmol}$ ) was dissolved in a mixture of $\mathrm{CH}_{3} \mathrm{CN}(5 \mathrm{~mL})$ and DMF $(1 \mathrm{~mL})$. Triethyl amine $(104 \mu \mathrm{L}, 0.75 \mathrm{mmol})$ and methyl propiolate $(67 \mu \mathrm{L}, 0.75 \mathrm{mmol})$ were then added and the reaction was left at r.t. for $1 \mathrm{~h}$ under stirring. The reaction progress was monitored by TLC analysis $\left(\mathrm{SiO}_{2}, \mathrm{AcOEt}\right.$, $\left.R_{f} \mathbf{9}=0.22, R_{f} \mathbf{1 1 a}=0.10\right)$. Acetonitrile was removed under reduced pressure and the DMF residue was dropped into water $(20 \mathrm{~mL})$. The brown precipitate was collected by filtration, washed with $\mathrm{H}_{2} \mathrm{O}$ and dried under vacuum to gave 11a in a pure form (141 mg, 57\%): ${ }^{1} \mathrm{H}-\mathrm{NMR}$ (DMSO- $\left.d_{6}\right) \delta 12.33$ $(\mathrm{s}, 1 \mathrm{H}), 7.76-7.23$ (m, 9H), 5.59 (br. s, 2H), 3.74 (s, 3H); ${ }^{13} \mathrm{C}-\mathrm{NMR}$ (DMSO- $d_{6}$ ) $\delta 165.2,156.7,141.1$, 140.1, 132.8, 131.9, 131.2, 130.0, 129.9, 129.5, 129.4, 128.4, 128.3, 128.2, 127.4, 127.3, 121.1, 113.4, 51.6; m.p. $198-199{ }^{\circ} \mathrm{C}$; $\mathrm{MS}\left(\mathrm{CI}^{+}\right): m / z=333[\mathrm{MH}]^{+}$; Anal. Calcd. for $\mathrm{C}_{19} \mathrm{H}_{15} \mathrm{~N}_{3} \mathrm{O}_{3}: \mathrm{C}, 68.46 ; \mathrm{H}, 4.54$; N, 12.61; Found: C, 68.41; H, 4.63; N 12.49 .

3-(Phenylcarbonyl)dibenzo[b,f]pyrrolo[2,3-d]azepine-8(1H)-carboxamide (11b). The oxime 9 (100 mg, $0.37 \mathrm{mmol})$ was dissolved in a mixture of $\mathrm{CH}_{3} \mathrm{CN}(2.5 \mathrm{~mL})$ and DMF $(0.5 \mathrm{~mL})$. Triethyl amine $(52 \mu \mathrm{L}$, $0.37 \mathrm{mmol}$ ) and phenyl propynone (49 $\mathrm{mg}, 0.37 \mathrm{mmol}$ ) were then added and the reaction was left at r.t. for $1 \mathrm{~h}$ under stirring. The reaction progress was monitored by TLC analysis $\left(\mathrm{SiO}_{2}, \mathrm{AcOEt}, R_{f} \mathbf{9}=0.22\right.$, $\left.R_{f} \mathbf{1 1 b}=0.13\right)$. Acetonitrile was removed under reduced pressure and the DMF residue was dropped into water $(10 \mathrm{~mL})$. The yellow precipitate was collected by filtration, washed with $\mathrm{H}_{2} \mathrm{O}$ and dried under vacuum to gave $\mathbf{1 1 b}$ in a pure form $(101 \mathrm{mg}, 71 \%)$ : ${ }^{1} \mathrm{H}-\mathrm{NMR}$ (DMSO- $\left.d_{6}\right) \delta 12.41(\mathrm{~s}, 1 \mathrm{H}), 7.82$ (d, $J=7.4 \mathrm{~Hz}, 1 \mathrm{H}), 7.76-7.08$ (m, 13H), 5.58 (br. s, 2H) ${ }^{13} \mathrm{C}-\mathrm{NMR}$ (DMSO- $d_{6}$ ) $\delta 191.1,156.9,141.0$, $140.2,139.8,135.5,133.4,132.7,131.5,130.2,130.1,129.9,129.5,129.4,129.1,128.9,128.8,128.3$, 128.2, 128.1, 127.6, 127.4, 122.7, 121.4; m.p. 265-266 ${ }^{\circ} \mathrm{C} ; \mathrm{MS}\left(\mathrm{CI}^{+}\right): m / z=380[\mathrm{MH}]^{+}, 337$ [(M-HNCO)H] $]^{+}$; Anal. Calcd. for $\mathrm{C}_{24} \mathrm{H}_{17} \mathrm{~N}_{3} \mathrm{O}_{2}$ : C, 75.97; H, 4.52; N, 11.08; Found: C, 75.78; H, 4.55; $\mathrm{N}, 11.21$.

3-[(4-Nitrophenyl)carbonyl]dibenzo[b,f]pyrrolo[2,3-d]azepine-8(1H)-carboxamide (11c). The oxime 9 (200 mg, $0.75 \mathrm{mmol})$ was dissolved in a mixture of $\mathrm{CH}_{3} \mathrm{CN}(4 \mathrm{~mL})$ and DMF (1 mL). Triethylamine $(104 \mu \mathrm{L}, 0.75 \mathrm{mmol})$ and $p$-nitrophenyl propynone $(131 \mathrm{mg}, 0.75 \mathrm{mmol})$ were then added and the reaction was left at r.t. for $1 \mathrm{~h}$ under stirring. The reaction progress was monitored by TLC analysis $\left(\mathrm{SiO}_{2}, \mathrm{AcOEt}, R_{f} \mathbf{9}=0.22, R_{f} \mathbf{1 1} \mathbf{c}=0.13\right)$. Acetonitrile was removed under reduced pressure and the 
DMF residue was dropped into water $(20 \mathrm{~mL})$. The brown precipitate was collected by filtration, washed with $\mathrm{H}_{2} \mathrm{O}$ and dried under vacuum to gave 11c in a pure form (249 $\mathrm{mg}, 78 \%$ ): ${ }^{1} \mathrm{H}-\mathrm{NMR}$ $\left(\right.$ DMSO- $\left.d_{6}\right) \delta 12.56$ (br. s, $\left.1 \mathrm{H}\right), 8.27-8.23(\mathrm{~m}, 2 \mathrm{H}), 8.02-7.98(\mathrm{~m}, 2 \mathrm{H}), 7.70-7.77(\mathrm{~m}, 1 \mathrm{H}), 7.60$ (s, 1H), 7.55-7.52 (m, 1H), 7.48-7.41 (m, 3H), 7.30-7.24 (m, 2H), 7.10 (dt, $J=7.6,1.2 \mathrm{~Hz}, 1 \mathrm{H}) 5.63$ (br. s, $2 \mathrm{H}$ ); ${ }^{13} \mathrm{C}-\mathrm{NMR}$ (DMSO- $d_{6}$ ) $\delta 189.1,156.5,149.4,145.2,140.8,139.7,132.7,131.6,131.2$, $130.8,130.4,129.8,129.3,128.0,127.9,127.2$, 127.1, 123.8, 121.7, 120.9; m.p. 188-189 ${ }^{\circ} \mathrm{C}$; MS $\left(\mathrm{CI}^{+}\right): m / z=425[\mathrm{MH}]^{+}, 382[(\mathrm{M}-\mathrm{HNCO}) \mathrm{H}]^{+}$; Anal. Calcd. for $\mathrm{C}_{21} \mathrm{H}_{15} \mathrm{~N}_{4} \mathrm{O}_{4}: \mathrm{C}, 67.92 ; \mathrm{H}, 3.80 ; \mathrm{N}$, 13.20; Found: C, 68.02; H, 3.93; N, 13.05 .

10-(Carbamoylhydrazono)-10,11-dihydro-5H-dibenzo[b,f]azepine-5-carboxamide (12). The compound was prepared following the procedure present in the literature and the spectroscopic data were in accordance with those reported [8]. Yield $=85 \%$.

8H-[1,2,3]Thiadiazolo[4,5-d]dibenzo[b,f]azepine-8-carboxamide (13). Thionyl chloride (5 $\mathrm{mL})$ was cooled to $-10{ }^{\circ} \mathrm{C}$ with an ice/ $\mathrm{NaCl}$ bath, 12 (496 mg, $\left.1.60 \mathrm{mmol}\right)$ was slowly added and the reaction mixture was left rise to r.t. under stirring. The reaction progress was monitored by TLC analysis $\left(\mathrm{SiO}_{2}\right.$, $\mathrm{CH}_{2} \mathrm{Cl}_{2} / \mathrm{EtOH} 95: 5, R_{f} \mathbf{1 2}=0.07, R_{f} \mathbf{1 3}=0.35$ ). When the reaction was complete (after about $2 \mathrm{~h}$ ), the mixture was added drop wise to water $(100 \mathrm{~mL})$ and the $\mathrm{pH}$ was set to 7 adding an aqueous solution of $\mathrm{NH}_{3}$. The yellow precipitate was collected and dried under vacuum to afford $\mathbf{1 3}$ in a pure form (392 $\mathrm{mg}$, 83\%): ${ }^{1} \mathrm{H}-\mathrm{NMR}\left(\mathrm{CDCl}_{3}\right) \delta 8.36(\mathrm{~d}, J=8.0 \mathrm{~Hz}, 1 \mathrm{H}), 7.72-7.59(\mathrm{~m}, 6 \mathrm{H}), 7.46(\mathrm{t}, J=7.5 \mathrm{~Hz}, 1 \mathrm{H}), 4.50$ (br. s, $2 \mathrm{H}) ;{ }^{13} \mathrm{C}-\mathrm{NMR}\left(\mathrm{CDCl}_{3}\right) \delta 156.6,155.9,150,140.6,140.2,132.4,132.0,131.5,130.8,130.5$, $130.4,129.5,129.2,129.2$, 127.3; m.p. $231-232{ }^{\circ} \mathrm{C}$; $\mathrm{MS}\left(\mathrm{CI}^{+}\right): m / z=295[\mathrm{MH}]^{+}, 323\left[\mathrm{M}^{+} \mathrm{C}_{2} \mathrm{H}_{5}\right]^{+}, 252$ [(M-HNCO)H] $]^{+}$; Anal. Calcd. for $\mathrm{C}_{15} \mathrm{H}_{10} \mathrm{~N}_{4} \mathrm{OS}$ : C, 61.21; H, 3.42; N, 19.04; Found: C, 61.28; H, 3.54; N, 19.11 .

8H-[1,2,3]Selenadiazolo[4,5-d]dibenzo[b,f]azepine-8-carboxamide (14). 12 (470 mg, $1.52 \mathrm{mmol}$ ) was dissolved in acetic acid $(5 \mathrm{~mL})$ and $\mathrm{SeO}_{2}(202 \mathrm{mg}, 1.82 \mathrm{mmol})$ was added portionwise while stirring. The temperature was rise to $118{ }^{\circ} \mathrm{C}$ and the mixture was left under stirring for $30 \mathrm{~min}$. The reaction progress was monitored by TLC analysis $\left(\mathrm{SiO}_{2}, \mathrm{CH}_{2} \mathrm{Cl}_{2} / \mathrm{EtOH} 95: 5, R_{f} \mathbf{1 2}=0.07, R_{f} \mathbf{1 4}=0.37\right)$. After cooling to r.t. water $(100 \mathrm{~mL})$ was added, the aqueous phase was extracted with ethyl acetate $(3 \times 40 \mathrm{~mL})$, the combined organic layers were dried $\left(\mathrm{Na}_{2} \mathrm{SO}_{4}\right)$ and the solvent was removed under reduced pressure to afford 14 as pink solid (250 mg, 48\%): ${ }^{1} \mathrm{H}-\mathrm{NMR}$ (DMSO- $\left.d_{6}\right) \delta 8.15(\mathrm{~d}, J=7.7 \mathrm{~Hz}, 1 \mathrm{H}), 7.69-7.64$ $(\mathrm{m}, 5 \mathrm{H}), 7.55(\mathrm{~m}, 1 \mathrm{H}), 7.42(\mathrm{~m}, 1 \mathrm{H}), 5.87$ (br. s, 2H); ${ }^{13} \mathrm{C}-\mathrm{NMR}$ (DMSO-d $) \delta 158.2,156.7,156.2$, 142.1, 141.4, 141.4, 135.2, 132.8, 131.4, 131.1, 130.9, 130.4, 130.3, 129.3, 129.0; m.p. 233-234 ${ }^{\circ} \mathrm{C}$; MS $\left(\mathrm{CI}^{+}\right): m / z=345\left[\mathrm{M}\left({ }^{82} \mathrm{Se}\right) \mathrm{H}\right]^{+}(8.7 \%), 343\left[\mathrm{M}\left({ }^{80} \mathrm{Se}\right) \mathrm{H}\right]^{+}(49.6 \%), 341\left[\mathrm{M}\left({ }^{78} \mathrm{Se}\right) \mathrm{H}\right]^{+}(23.7 \%), 340$ $\left[\mathrm{M}\left({ }^{77} \mathrm{Se}\right) \mathrm{H}\right]^{+}(7.6 \%), 339\left[\mathrm{M}\left({ }^{76} \mathrm{Se}\right) \mathrm{H}\right]^{+}(9.3 \%), 317\left[\left(\mathrm{M}\left({ }^{82} \mathrm{Se}\right)-\mathrm{N}_{2}\right) \mathrm{H}\right]^{+}, 315\left[\left(\mathrm{M}\left({ }^{80} \mathrm{Se}\right)-\mathrm{N}_{2}\right) \mathrm{H}\right]^{+}, 313$ $\left[\left(\mathrm{M}\left({ }^{78} \mathrm{Se}\right)-\mathrm{N}_{2}\right) \mathrm{H}\right]^{+}, 312\left[\left(\mathrm{M}\left({ }^{77} \mathrm{Se}\right)-\mathrm{N}_{2}\right) \mathrm{H}\right]^{+}, 311\left[\left(\mathrm{M}\left({ }^{76} \mathrm{Se}\right)-\mathrm{N}_{2}\right) \mathrm{H}\right]^{+}$; Anal. Calcd. for $\mathrm{C}_{15} \mathrm{H}_{10} \mathrm{~N}_{4} \mathrm{OSe}: \mathrm{C}$, 52.80; H, 2.95; N, 16.42; Found: C, 52.74; H, 3.02; N, 16.26 .

10-Bromo-11-oxo-10,11-dihydro-5H-dibenzo[b,f]azepine-5-carboxamide (16). The compound was prepared following the procedure present in the literature and the spectroscopic data were in accordance with those reported [26]. Yield $=92 \%$. 
2-Amino-8H-dibenzo[b,f][1,3]thiazolo[4,5-d]azepine-8-carboxamide (17). Compound 16 (300 mg, $0.91 \mathrm{mmol})$ and thiourea $(205 \mathrm{mg}, 2.69 \mathrm{mmol})$ were dissolved in ethanol $(13 \mathrm{~mL})$. The well stirred reaction mixture was brought to reflux for $3 \mathrm{~h}$. The reaction progress was monitored by TLC analysis $\left(\mathrm{SiO}_{2}, \mathrm{AcOEt} / \mathrm{EtOH} 9: 1, R_{f} \mathbf{1 7}=0.28\right)$. After cooling to r.t., the reaction mixture was dropped into water $(100 \mathrm{~mL})$, the white precipitate was collected and dried under vacuum to afford $\mathbf{1 7}$ in a pure form (120 mg, 43\%). ${ }^{1} \mathrm{H}-\mathrm{NMR}\left(\mathrm{DMSO}-d_{6}\right) \delta 7.78(\mathrm{~d}, J=7.5 \mathrm{~Hz}, 1 \mathrm{H}), 7.50-7.36(\mathrm{~m}, 9 \mathrm{H}), 5.65$ (br. s, 2H); ${ }^{13} \mathrm{C}-\mathrm{NMR}\left(\mathrm{DMSO}-d_{6}\right) \delta 167.5,157.0,140.4,139.9,132.9,131.4,130.4,130.3,130.1,129.1,128.7$, 128.6, 128.3, 120.6; m.p. 215-217 ${ }^{\circ} \mathrm{C}$; MS $\left(\mathrm{CI}^{+}\right): m / z=309[\mathrm{MH}]^{+}, 266[(\mathrm{M}-\mathrm{HNCO}) \mathrm{H}]^{+}$; Anal. Calcd. for $\mathrm{C}_{16} \mathrm{H}_{12} \mathrm{~N}_{4} \mathrm{OS}$ : C, 62.32; H, 3.92; N, 18.17; Found: C, 62.43; H, 3.97; N, 17.98 .

2-Amino-8H-dibenzo[b,f][1,3] oxazolo[4,5-d]azepine-8-carboxamide (20). 16 (200 mg, $0.60 \mathrm{mmol})$ and urea (181 mg, $3.02 \mathrm{mmol})$ were dissolved in $n$-butyl alcohol $(3 \mathrm{~mL})$, under a nitrogen atmosphere. The well stirred reaction mixture was brought to reflux for $16 \mathrm{~h}$. The reaction progress was monitored by TLC analysis $\left(\mathrm{SiO}_{2}, \mathrm{CH}_{2} \mathrm{Cl}_{2} / \mathrm{EtOH} 95: 5, R_{f} \mathbf{1 6}=0.33, R_{f} \mathbf{2 0}=0.03\right)$. After cooling to r.t., an aqueous solution of $\mathrm{NaHCO}_{3}$ was added to the reaction mixture and the solvent was removed under reduced pressure. Flash column chromatography $\left(\mathrm{SiO}_{2}, \mathrm{CH}_{2} \mathrm{Cl}_{2} / \mathrm{EtOH} 9: 1, R_{f}=0.16\right)$ afforded 20 as white solid (56 mg, 32\%): ${ }^{1} \mathrm{H}-\mathrm{NMR}\left(\mathrm{CDCl}_{3}\right) \delta 7.80(\mathrm{~m}, 1 \mathrm{H}), 7.54-7.33(\mathrm{~m}, 7 \mathrm{H}), 5.79$ (br. s, $\left.2 \mathrm{H}\right), 5.04$ (br. s, 2H); ${ }^{13} \mathrm{C}-\mathrm{NMR}\left(\mathrm{CDCl}_{3}\right) \delta 161.1,158.1,137.0,136.0,130.9,130.1,129.8,129.6,129.0,128.9$, 128.6, 127.5, 127.0, 124.2; m.p. $224-226{ }^{\circ} \mathrm{C}$; $\mathrm{MS}\left(\mathrm{CI}^{+}\right): m / z=293[\mathrm{MH}]^{+}, 250[(\mathrm{M}-\mathrm{HNCO}) \mathrm{H}]^{+}$; Anal. Calcd. for $\mathrm{C}_{16} \mathrm{H}_{12} \mathrm{~N}_{4} \mathrm{O}_{2}$ : C, 65.75; H, 4.14; N, 19.17; Found: C, 65.44; H, 4.11; N, 19.28.

10H-Dibenzo[b,f]thiazolo[1',2':1,2]imidazo[4,5-d] azepine-10-carboxamide (21). Compound 16 (200 mg, $0.60 \mathrm{mmol})$ and 2-aminothiazole $(121 \mathrm{mg}, 1.21 \mathrm{mmol})$ were dissolved in $n$-butyl alcohol $(20 \mathrm{~mL})$. The well stirred reaction mixture was brought to reflux for $6 \mathrm{~h}$. The reaction progress was monitored by TLC analysis $\left(\mathrm{SiO}_{2}, \mathrm{CH}_{2} \mathrm{Cl}_{2} / \mathrm{EtOH} 95: 5, R_{f} \mathbf{1 6}=0.33, R_{f}\right.$ 2-aminothiazole $\left.=0.11, R_{f} \mathbf{2 1}=0.06\right)$. After cooling to r.t., water was added to the reaction mixture and the solvent was removed under reduced pressure. Flash column chromatography $\left(\mathrm{SiO}_{2}, \mathrm{CH}_{2} \mathrm{Cl}_{2} / \mathrm{EtOH} 9: 1, R_{f}=0.27\right)$ gave 21 as ochre solid (113 mg, 56\%): ${ }^{1} \mathrm{H}-\mathrm{NMR}\left(\mathrm{DMSO}-d_{6}\right) \delta 8.33(\mathrm{~d}, J=4.4 \mathrm{~Hz}, 1 \mathrm{H}), 7.92(\mathrm{~m}, 1 \mathrm{H}), 7.82(\mathrm{~m}, 1 \mathrm{H}), 7.61$ $(\mathrm{m}, 1 \mathrm{H}), 7.56-7.45(\mathrm{~m}, 7 \mathrm{H}), 5.62$ (br. s, 2H); ${ }^{13} \mathrm{C}-\mathrm{NMR}$ (DMSO- $\left.d_{6}\right) \delta 169.8,157.1,151.6,143.8$, 139.9, 139.4, 132.9, 131.1, 130.2, 129.9, 129.5, 128.9, 128.7, 128.3, 128.2, 125.4, 120.3, 115.5; m.p. 257-258 ${ }^{\circ} \mathrm{C}$; MS $\left(\mathrm{CI}^{+}\right): m / z=333[\mathrm{MH}]^{+}, 290[(\mathrm{M}-\mathrm{HNCO}) \mathrm{H}]^{+}$; Anal. Calcd. for $\mathrm{C}_{18} \mathrm{H}_{12} \mathrm{~N}_{4} \mathrm{OS}: \mathrm{C}$, 65.04; H, 3.64; N, 16.86; Found: C, 65.19; H, 3.59; N, 16.82.

10H-Dibenzo[b,f]pyrido[1',2':1,2]imidazo[4,5-d]azepine-10-carboxamide (22). Compound 16 (300 mg, $0.91 \mathrm{mmol})$ and 2-aminopyridine (128 $\mathrm{mg}, 1.36 \mathrm{mmol})$ were dissolved in $n$-butyl alcohol $(30 \mathrm{~mL})$. The well stirred reaction mixture was brought to reflux for $1 \mathrm{~h}$. The reaction progress was monitored by TLC analysis $\left(\mathrm{SiO}_{2}, \mathrm{CH}_{2} \mathrm{Cl}_{2} / \mathrm{EtOH} 95: 5, R_{f} \mathbf{1 6}=0.33, R_{f}\right.$-aminopyridine $\left.=0.18, R_{f} \mathbf{2 2}=0.06\right)$. After cooling to r.t., water was added to the reaction mixture and the solvent was removed under reduced pressure. Flash column chromatography $\left(\mathrm{SiO}_{2}, \mathrm{CH}_{2} \mathrm{Cl}_{2} / \mathrm{EtOH} 9: 1, R_{f}=0.32\right)$ gave 22 as pink solid (157 mg, 53\%): ${ }^{1} \mathrm{H}-\mathrm{NMR}\left(\mathrm{CDCl}_{3}\right) \delta 8.71(\mathrm{~d}, J=7.0 \mathrm{~Hz}, 1 \mathrm{H}), 7.97-6.94(\mathrm{~m}, 11 \mathrm{H}), 5.45$ (br. s, 2H); ${ }^{13} \mathrm{C}-\mathrm{NMR}\left(\mathrm{DMSO}-d_{6}\right) \delta 156.9,146.4,143.1,141.9,141.2,135.4,133.0,131.1,130.2,129.9,129.6$, $129.0,128.8,128.5,128.3,126.9,125.9,125.5,118.5,112.9$; m.p. $255-256{ }^{\circ} \mathrm{C} ; \mathrm{MS}\left(\mathrm{CI}^{\dagger}\right): m / z=327$ 
$[\mathrm{MH}]^{+}, 284[(\mathrm{M}-\mathrm{HNCO}) \mathrm{H}]^{+}$; Anal. Calcd. for $\mathrm{C}_{20} \mathrm{H}_{14} \mathrm{~N}_{4} \mathrm{O}: \mathrm{C}, 73.61 ; \mathrm{H}, 4.32 ; \mathrm{N}, 17.17$; Found: C, $73.69 ; \mathrm{H}, 4.28 ; \mathrm{N}, 17.24$.

10H-Dibenzo[b,f]pyrimido[1',2':1,2] imidazo[4,5-d] azepine-10-carboxamide (23). Compound 16 (100 mg, $0.30 \mathrm{mmol})$ and 2-aminopyrimidine $(29 \mathrm{mg}, 0.30 \mathrm{mmol})$ were dissolved in $n$-butyl alcohol $(5 \mathrm{~mL})$, under nitrogen atmosphere. The well stirred reaction mixture was brought to reflux for $8 \mathrm{~h}$. The reaction progress was monitored by TLC analysis $\left(\mathrm{SiO}_{2}, \mathrm{CH}_{2} \mathrm{Cl}_{2} / \mathrm{EtOH} 8: 2, R_{f} \mathbf{1 6}=0.71\right.$, $R_{f}$ 2-amino-pyrimidine $=0.36, R_{f} \mathbf{2 3}=0.28$ ). After cooling to r.t., an aqueous solution of $\mathrm{K}_{2} \mathrm{CO}_{3}$ $(0.30 \mathrm{mmol}, 10 \mathrm{~mL})$ was added to the reaction mixture and the solvent was removed under reduced pressure. Flash column chromatography $\left(\mathrm{SiO}_{2}, \mathrm{CH}_{2} \mathrm{Cl}_{2} / \mathrm{EtOH} 9: 1, R_{f}=0.21\right)$ afforded 23 as white solid (33 mg, 34\%): ${ }^{1} \mathrm{H}-\mathrm{NMR}$ (DMSO- $\left.d_{6}\right) \delta 9.29(\mathrm{~m}, 1 \mathrm{H}), 8.72(\mathrm{~m}, 1 \mathrm{H}), 8.06(\mathrm{~m}, 1 \mathrm{H}), 7.97(\mathrm{~m}, 1 \mathrm{H}), 7.69-7.49$ $(\mathrm{m}, 6 \mathrm{H}), 7.44(\mathrm{~m}, 1 \mathrm{H}), 5.69$ (br. s, $2 \mathrm{H}) ;{ }^{13} \mathrm{C}-\mathrm{NMR}$ (DMSO- $\left.d_{6}\right) \delta 152.5,134.6,131.2,130.8,130.2$, 130.0, 129.2, 128.8, 128.7, 126.0, 110.5; m.p. 259-261 ${ }^{\circ} \mathrm{C} \mathrm{dec}$; $\mathrm{MS}\left(\mathrm{CI}^{+}\right): m / z=328[\mathrm{MH}]^{+}, 285$ [(M-HNCO)H] $]^{+}$; Anal. Calcd. for $\mathrm{C}_{19} \mathrm{H}_{13} \mathrm{~N}_{5} \mathrm{O}: \mathrm{C}, 69.71 ; \mathrm{H}, 4.00$; N, 21.39; Found: C, 69.60; H, 4.13; $\mathrm{N}, 21.33$.

5H-Dibenzo[b,f]azepine-10,11-dione (26). Oxcarbazepine (1, $5.0 \mathrm{~g}, 19.82 \mathrm{mmol})$ and $\mathrm{SeO}_{2}(5.4 \mathrm{~g}$, $48.67 \mathrm{mmol})$ in dioxane $(100 \mathrm{~mL})$ were brought to reflux under vigorous stirring for $7 \mathrm{~h}$. The reaction progress was monitored by TLC analysis $\left(\mathrm{SiO}_{2}, \mathrm{CH}_{2} \mathrm{Cl}_{2} / \mathrm{EtOH} 95: 5, R_{f} \mathbf{1}=0.27, R_{f} \mathbf{2 6}=0.56\right)$. After cooling to r.t. the orange precipitate was filtered and dried under vacuum to afford $\mathbf{2 6}(4.0 \mathrm{~g}, 90 \%)$ : the spectroscopic data were in accordance with those reported in the literature [30].

10H-Quinoxalino[2,3-d]dibenzo[b,f]azepine (27). Compound 26 (100 mg, $0.45 \mathrm{mmol})$ and 1,2-diaminobenzene ( $49 \mathrm{mg}, 0.45 \mathrm{mmol})$ in $\mathrm{AcOH}(2 \mathrm{~mL})$ were refluxed for $1 \mathrm{~h}$ under stirring. The reaction progress was monitored by TLC analysis $\left(\mathrm{SiO}_{2}, \mathrm{CH}_{2} \mathrm{Cl}_{2} / \mathrm{EtOH} 95: 5, R_{f} \mathbf{2 6}=0.54\right.$, $R_{f} 1$,2-diaminobenzene $\left.=0.23, R_{f} \mathbf{2 7}=0.69\right)$. The reaction mixture was left cooling to r.t. and added dropwise to stirred ice/water $(25 \mathrm{~mL})$, the yellow precipitate was collected by filtration, washed with water and dried under vacuum to afford 27 (64 mg, 49\%): the spectroscopic data were in accordance with those reported in the literature [30].

9H-Dibenzo[b,f]pyrazino[2,3-d] azepine-2,3-dicarbonitrile (28). Compound 26 (100 mg, $0.45 \mathrm{mmol})$ and diaminomalonitrile (49 $\mathrm{mg}, 0.45 \mathrm{mmol})$ in $\mathrm{AcOH}(2 \mathrm{~mL})$ were refluxed for $1 \mathrm{~h}$ under stirring. The reaction progress was monitored by TLC analysis $\left(\mathrm{SiO}_{2}, \mathrm{CH}_{2} \mathrm{Cl}_{2} / \mathrm{EtOH} 95: 5, R_{f} \mathbf{2 6}=0.54\right.$, $R_{f} \mathbf{2 8}=0.73$ ). The reaction mixture was left cooling to r.t., the dark red precipitate was collected by filtration and dried under vacuum to afford $28(86 \mathrm{mg}, 65 \%)$ : ${ }^{1} \mathrm{H}-\mathrm{NMR}$ (DMSO- $\left.d_{6}\right) \delta 8.13(\mathrm{~s}, 1 \mathrm{H}), 7.70$ $(\mathrm{dd}, J=7.1,1.4 \mathrm{~Hz}, 2 \mathrm{H}), 7.43(\mathrm{td}, J=8.1,1.5 \mathrm{~Hz}, 2 \mathrm{H}), 7.14(\mathrm{t}, J=7.6 \mathrm{~Hz}, 2 \mathrm{H}), 7.11(\mathrm{~d}, J=8.1 \mathrm{~Hz}$, $2 \mathrm{H}) ;{ }^{13} \mathrm{C}-\mathrm{NMR}\left(\mathrm{DMSO}-d_{6}\right) \delta 156.3,153.6,133.8,132.6,131.6,126.7,124.7,121.4,115.21 ; \mathrm{MS}\left(\mathrm{CI}^{+}\right)$: $m / z=296[\mathrm{MH}]^{+}$; Anal. Calcd. for $\mathrm{C}_{18} \mathrm{H}_{9} \mathrm{~N}_{5}: \mathrm{C}, 73.21 ; \mathrm{H}, 3.07$; N, 23.72; Found: C, 73.52; H, 3.04; $\mathrm{N}, 23.48$.

2,9-Dihydro-3H-dibenzo[b,f][1,2,4]triazino[5,6-d]azepin-3-one (29). Semicarbazide hydrochloride ( $50 \mathrm{mg}, 0.45 \mathrm{mmol}$ ) was dissolved in $\mathrm{H}_{2} \mathrm{O}(0.5 \mathrm{~mL})$, this solution was added to a stirred solution of 26 $(100 \mathrm{mg}, 0.45)$ in $\mathrm{AcOH}(6 \mathrm{~mL})$. The mixture was then refluxed for $1 \mathrm{~h}$. The reaction progress was 
monitored by TLC analysis $\left(\mathrm{SiO}_{2}, \mathrm{CH}_{2} \mathrm{Cl}_{2} / \mathrm{EtOH} 95: 5, R_{f} \mathbf{2 6}=0.54, R_{f} \mathbf{2 9}=0.25\right)$. When the reaction was complete, the solvent was removed under vacuum, water was added to the residue and the aqueous phase was extracted with AcOEt $(3 \times 10 \mathrm{~mL})$. The combined organic layers were dried $\left(\mathrm{Na}_{2} \mathrm{SO}_{4}\right)$ and the solvent was removed under reduced pressure. Flash column chromatography $\left(\mathrm{SiO}_{2}, \mathrm{CH}_{2} \mathrm{Cl}_{2} / \mathrm{EtOH}\right.$ 95:5, $R_{f}=0.25$ ) gave 29 as red solid (23 mg, 19\%): ${ }^{1} \mathrm{H}-\mathrm{NMR}$ (DMSO- $\left.d_{6}\right) \delta 8.23$ (br. s, $\left.1 \mathrm{H}\right), 7.89$ (dd, $J=7.9,1.6 \mathrm{~Hz}, 1 \mathrm{H}), 7.52(\mathrm{dd}, J=7.8,1.5 \mathrm{~Hz}, 1 \mathrm{H}), 7.45(\mathrm{td}, J=7.8,1.6 \mathrm{~Hz}, 1 \mathrm{H}), 7.33$ (td, $J=7.6,1.5 \mathrm{~Hz}$, $1 \mathrm{H}), 7.17-7.14(\mathrm{~m}, 2 \mathrm{H}), 7.10-7.04(\mathrm{~m}, 2 \mathrm{H}), 5.75(\mathrm{~s}, 1 \mathrm{H}),{ }^{13} \mathrm{C}-\mathrm{NMR}$ (DMSO-d 6 ) $\delta 167.5,153.9,151.4$, $148.4,141.7,134.2,131.8,131.1,129.9,125.2,124.3,123.7,122.9,120.8,120.2$; m.p. $227-230{ }^{\circ} \mathrm{C}$ dec.; MS $\left(\mathrm{CI}^{+}\right): m / z=263[\mathrm{MH}]^{+}$; Anal. Calcd. for $\mathrm{C}_{15} \mathrm{H}_{10} \mathrm{~N}_{4} \mathrm{O}: \mathrm{C}, 68.69 ; \mathrm{H}, 3.84$; N, 21.36; Found: C, $68.52 ; \mathrm{H}, 3.95 ; \mathrm{N}, 21.24$.

2-Phenyl-1,8-dihydrodibenzo[b,f]imidazo[4,5-d]azepine (30). Compound 26 (300 mg, $1.34 \mathrm{mmol}$ ), benzaldehyde (143 mg, $1.34 \mathrm{mmol})$ and ammonium acetate $(268 \mathrm{mg}, 3.48 \mathrm{mmol})$ were dissolved in $\mathrm{AcOH}(12 \mathrm{~mL})$. The reaction mixture was brought to $80{ }^{\circ} \mathrm{C}$ for $1 \mathrm{~h}$ under stirring. The reaction progress was monitored by TLC analysis $\left(\mathrm{SiO}_{2}, \mathrm{CH}_{2} \mathrm{Cl}_{2} / \mathrm{EtOH} 95: 5, R_{f} \mathbf{2 6}=0.54, R_{f} \mathbf{3 0}=0.28\right)$. The mixture was cooled to r.t and dropped into ice/water $(50 \mathrm{~mL})$. The aqueous suspension was extracted with AcOEt $(3 \times 20 \mathrm{~mL})$ and the unreacted diketone was removed by filtration. The organic phase was dried $\left(\mathrm{Na}_{2} \mathrm{SO}_{4}\right)$ and the solvent was removed under reduced pressure. Flash column chromatography $\left(\mathrm{SiO}_{2}, \mathrm{CH}_{2} \mathrm{Cl}_{2} / \mathrm{EtOH} 95: 5, R_{f}=0.28\right)$ gave 30 in a pure form $(115 \mathrm{mg}, 28 \%)$ : ${ }^{1} \mathrm{H}-\mathrm{NMR}\left(\mathrm{DMSO}-d_{6}\right) \delta$ 12.38 (br. s, 1H), $8.09(\mathrm{~m}, 2 \mathrm{H}), 7.62(\mathrm{~m}, 1 \mathrm{H}), 7.49(\mathrm{~m}, 2 \mathrm{H}), 7.41(\mathrm{~m}, 2 \mathrm{H}), 7.22(\mathrm{~s}, 1 \mathrm{H}), 7.06(\mathrm{~m}, 2 \mathrm{H})$, 6.94-6.84 (m, 4H) ${ }^{13} \mathrm{C}-\mathrm{NMR}\left(\mathrm{DMSO}-d_{6}\right) \delta 148.3,147.9,147.8,139.2,131.1,129.9,129.6,129.5$, 129.5, 129.3, 129.1, 127.7, 127.3, 126.7, 126.2, 126.2, 123.2, 123.0, 122.9, 120.8, 120.5; m.p. 102-103 ${ }^{\circ} \mathrm{C}$; MS $\left(\mathrm{CI}^{+}\right): m / z=310[\mathrm{MH}]^{+}$; Anal. Calcd. for $\mathrm{C}_{21} \mathrm{H}_{15} \mathrm{~N}_{3}: \mathrm{C}, 81.53$; H, 4.89; N, 13.58; Found: C, 81.58; $\mathrm{H}, 4.95 ; \mathrm{N}, 13.46$.

9H-Dibenzo[b,f]pyrido[1',2':1,5]pyrazolo[3,4-d]azepine-9-carboxamide (32). Oxcarbazepine (1, $300 \mathrm{mg}$, $1.19 \mathrm{mmol}$ ), 1-aminopyridinium iodide $(317 \mathrm{mg}, 1.43 \mathrm{mmol}$ ) and potassium carbonate (493 $\mathrm{mg}$, $3.57 \mathrm{mmol})$ were dissolved in a mixture of $\mathrm{H}_{2} \mathrm{O}(20 \mathrm{~mL})$ and $i$-PrOH $(20 \mathrm{~mL})$. The temperature was rise to $100{ }^{\circ} \mathrm{C}$ and the mixture was left under stirring for $2 \mathrm{~h}$. The reaction progress was monitored by TLC analysis $\left(\mathrm{SiO}_{2}, \mathrm{CH}_{2} \mathrm{Cl}_{2} / \mathrm{EtOH} 95: 5, R_{f} \mathbf{1}=0.27, R_{f} \mathbf{3 2}=0.18\right)$. Isopropanol was removed under reduced pressure and the aqueous residue was extracted with ethyl acetate $(3 \times 20 \mathrm{~mL})$. The combined organic layers were dried $\left(\mathrm{Na}_{2} \mathrm{SO}_{4}\right)$ and the solvent removed in vacuum. Flash column chromatography $\left(\mathrm{SiO}_{2}, \mathrm{CH}_{2} \mathrm{Cl}_{2} / \mathrm{EtOH} 9: 1, R_{f}=0.36\right)$ gave 32 as red solid $(85 \mathrm{mg}, 22 \%):{ }^{1} \mathrm{H}-\mathrm{NMR}\left(\mathrm{DMSO}-d_{6}\right) \delta 8.91$ $(\mathrm{d}, J=6.9 \mathrm{~Hz}, 1 \mathrm{H}), 8.07(\mathrm{~d}, J=9.0 \mathrm{~Hz}, 1 \mathrm{H}), 7.94(\mathrm{~m}, 1 \mathrm{H}), 7.83(\mathrm{~m}, 1 \mathrm{H}), 7.61-7.40(\mathrm{~m}, 7 \mathrm{H}), 7.12$ (t, $J=6.8 \mathrm{~Hz}, 1 \mathrm{H}), 5.60$ (br. s, 2H); ${ }^{13} \mathrm{C}-\mathrm{NMR}\left(\mathrm{DMSO}-d_{6}\right) \delta 157.1,149.9,142.7,141.2,138.0,131.6$, 131.5, 130.9, 130.7, 130.5, 130.2, 129.1, 128.9, 128.7, 128.4, 128.2, 126.3, 118.3, 114.7, 108.6; m.p. 254-255 ${ }^{\circ} \mathrm{C}$; $\mathrm{MS}\left(\mathrm{CI}^{+}\right): m / z=328[\mathrm{MH}]^{+}, 284[(\mathrm{M}-\mathrm{HNCO}) \mathrm{H}]^{+}$; Anal. Calcd. for $\mathrm{C}_{20} \mathrm{H}_{14} \mathrm{~N}_{4} \mathrm{O}: \mathrm{C}, 73.61$; H, 4.32; N, 17.17; Found: C, 73.49; H, 4.43; N, 17.10 . 


\section{Conclusions}

To summarize, a structurally diverse heterocyclic library sharing a common dibenzo $[b, f]$ azepine scaffold, decorated with $[d]$-fused heterocycles has been reported, thus providing a foundation for the further investigation of their biological activities.

\section{Acknowledgments}

We express our gratitude to Trifarma SpA, Ceriano Laghetto, Italy for the generous loan of oxcarbazepine.

\section{Conflicts of Interest}

The authors declare no conflict of interest.

\section{References}

1. Scbindler, W.; Blattner, H. Verfahren zur Herstellung von neuen $N$-heterocyclischen Verbindungen. CH Patent 403,767, 15 December 1965.

2. Schindler, W. 10-Oxo-10,11-dihydro-dibenzazepine Derivative. U.S. Patent 3,642,775, 4 March 1970.

3. Kalis, M.M.; Huff, N.A. Oxcarbazepine, an antiepileptic agent. Clin. Ther. 2001, 23, 680-700.

4. Shorvon, S. Oxcarbazepine, a review. Seizure 2000, 9, 75-79.

5. Schütz, H.; Feldmann, K.F.; Faigle, J.W.; Kriemler, H.P.; Winkler, T. The metabolism of ${ }^{14} \mathrm{C}$-oxcarbazepine in man. Xenobiotica 1986, 16, 769-778.

6. Hempel, A.; Camerman, N.; Camerman, A.; Mastropaolo, D. Oxcarbazepine: Structure and anticonvulsant activity. Acta Cryst. 2005, E61, o1313-o1315.

7. Benes, J.; Parada, A.; Figueiredo, A.A.; Alves, P.C.; Freitas, A.P.; Learmonth, D.A.; Cunha, R.A.; Garrett, J.; Soares-da-Silva, P. Anticonvulsant and sodium channel-blocking properties of novel 10,11-dihydro-5H-dibenz[ $b$, $]$ azepine-5-carboxamide derivatives. J. Med. Chem. 1999, 42, 2582-2587.

8. Learmonth, D.A.; Benes, J.; Parada, A.; Hainzl, D.; Beliaev, A.; Bonifàcio, M.J.; Matias, P.M.; Carrondo, M.A.; Garrett, J.; Soares-da-Silva, P. Synthesis, anticonvulsant properties and pharmacokinetic profile of novel 10,11-dihydro-10-oxo-5H-dibenz[ $b, f]$ azepine-5-carboxamide derivatives. Eur. J. Med. Chem. 2001, 36, 227-236.

9. Cravotto, G.; Giovenzana, G.B.; Maspero, A.; Pilati, T.; Penoni, A.; Palmisano, G. Allylindation of $1 \mathrm{H}$-indole-3-carboxaldehyde in the presence of azoles-revisited. Tetrahedron Lett. 2006, 47, 6439-6443.

10. Colombo, F.; Cravotto, G.; Palmisano, G.; Penoni, A.; Sisti, M. Three-component indium-mediated domino allylation of $1 \mathrm{H}$-indole-3-carbaldehyde with electron-rich (hetero)arenes: Highly efficient access to variously functionalized indolylbutenes. Eur. J. Org. Chem. 2008, 2801-2807.

11. Penoni, A.; Palmisano, G.; Broggini, G.; Kadowaki, A.; Nicholas, K.M. Efficient synthesis of $\mathrm{N}$-methoxyindoles via alkylative cycloaddition of nitrosoarenes with alkynes. J. Org. Chem. 2006, $71,823-825$. 
12. Penoni, A.; Palmisano, G.; Zhao, Y.L.; Houk, K.N.; Volkman, J.; Nicholas, K.M. On the mechanism of nitrosoarene-alkyne cycloaddition. J. Am. Chem. Soc. 2009, 131, 653-661.

13. Tibiletti, F.; Simonetti, M.; Nicholas, K.M.; Palmisano, G.; Parravicini, M.; Imbesi, F.; Tollari, S.; Penoni, A. One-pot synthesis of meridianins and meridianin analogues via indolization of nitrosoarenes. Tetrahedron 2010, 66, 1280-1288.

14. Benedetti, E.; Lomazzi, M.; Tibiletti, F.; Goddard, J.P.; Fensterbank, L.; Malacria, M.; Palmisano, G.; Penoni, A. Synthesis of nitrogen-containing heterocycles via ring-closing ene-ene and ene-yne metathesis reactions: An easy access to 1- and 2-benzazepine scaffolds and five- and six-membered lactams. Synthesis 2012, 44, 3523-3533.

15. Fischer, E.; Hess, O. Synthese von Indolderivaten. Ber. Dtsch. Chem. Ges. 1884, 17, 559-568.

16. Robinson, B. The Fischer indole synthesis. Chem. Rev. 1963, 63, 373-401.

17. Piloty, O. Synthese von Pyrrolderivaten: Pyrrole aus Succinylobernsteinsäureester, Pyrrole aus Azinen. Chem. Ber. 1910, 43, 489-498.

18. Robinson, G.M.; Robinson, R. A new synthesis of tetraphenylpyrrole. J. Chem. Soc. 1918, 113, 639-645.

19. Bhatt, M.V.; Reddy, G.S. A new synthesis of oxazoles. Tetrahedron Lett. 1980, 21, 2359-2360.

20. Tanoury, G.J. Name Reactions in Heterocyclic Chemistry II; John Wiley \& Sons: Hoboken, NJ, USA, 2011; pp. 72-82.

21. Trofimov, B.; Mikhaleva, A.I. Further development of the ketoxime-based pyrrole synthesis. Heterocycles 1994, 37, 1193-1232.

22. Hurd, C.D.; Mori, R.I. On Acylhydrazones and 1,2,3-thiadiazoles. J. Am. Chem. Soc. 1955, 77, 5359-5364.

23. Lalezari, I.; Shafiee, A.; Yalpani, M. A novel synthesis of selenium heterocycles: Substituted 1,2,3-selenadiazoles. Tetrahedron Lett. 1969, 10, 5105-5106.

24. Huazhou, Y.; Yongjian, F.; Tao, L.; Yongzhou, H. Synthesis of 4-aryl-3,4-dihydro- and 2,4-diaryl-2,3,3a,4-tetrahydrochromeno[3,4-d][1,2,3]diazaphospholes. Synlett 2007, 2007, 2513-2516.

25. Erian, A.W.; Sherif, S.M.; Gaber, H.M. The chemistry of $\alpha$-haloketones and their utility in heterocyclic synthesis. Molecules 2003, 8, 793-865.

26. Heckendorn, R. Synthesis of trans-10,11-dihydro-10,11-dihydroxy-5H-dibenz $[b, f]$ azepine-5carboxamide, a major metabolite of carbamazepine. Helv. Chim. Acta 1987, 70, 1955-1962.

27. Chai, W.; Kwok, A.; Wong, V.; Carruthers, N.I.; Wu, J. A practical parallel synthesis of 2-substituted indolizines. Synlett 2003, 13, 2086-2088.

28. Schmieder-van de Vondervoort, L.; Bouttemy, S.; Heu, F.; Weissenböck, K.; Alsters, P.L. Low temperature, high conversion, liquid-phase benzylic oxidation with dioxygen by metal/NHPI-catalyzed Co-oxidation with benzaldehyde. Eur. J. Org. Chem. 2003, 578-586.

29. Kaufmann, D.; Fünfschilling, P.C.; Beutler, U.; Hoehn, P.; Lohse, O.; Zaugg, W. A new synthesis of oxcarbazepine using a Friedel-Crafts cyclization strategy. Tetrahedron Lett. 2004, 45, 5275-5278.

30. Chen, C.T.; Lin, J.S.; Moturu, M.V.R.K.; Lin, Y.W.; Yi, W.; Tao, Y.T.; Chien, C.H. Doubly ortho-linked quinoxaline/triarylamine hybrid as a bifunctional, dipolar electroluminescent template for optoelectronic applications. Chem. Commun. 2005, 3980-3982. 
31. Debus, H. Üeber die Einwirkung des Ammoniaks auf Glyoxal. Justus Liebigs Ann. Chem. 1858, 107, 199-208.

32. Huang, Y.; Dömling, A. The Gewald multicomponent reaction. Mol. Diver. 2011, 15, 3-33.

33. Sibor, J.; Pazdera, P. Syntheses of some new five-membered heterocycles containing selenium and tellurium. Molecules 1996, 1, 157-162.

34. Cossy, J.; Poitevin, C.; Sallé, L.; Gomez-Pardo, D. The thermal rearrangement of $N$-alkyl- $N$ vinylpropargylamines into 2-methylpyrroles. A new synthesis of annulated $[b]$ pyrroles. Tetrahedron Lett. 1996, 37, 6709-6710.

35. Shvekhgeimer, G.A. The Pfitzinger reaction. Chem. Heterocycl. Compd. 2004, 40, 257-294.

Sample Availability: Samples of the compounds are available from the authors.

(C) 2013 by the authors; licensee MDPI, Basel, Switzerland. This article is an open access article distributed under the terms and conditions of the Creative Commons Attribution license (http://creativecommons.org/licenses/by/3.0/). 